University of Pennsylvania Carey Law School

Penn Law: Legal Scholarship Repository

Faculty Scholarship at Penn Law

2000

\title{
Vern Countryman and the Path of Progressive (and Populist) Bankruptcy Scholarship
}

David A. Skeel Jr.

University of Pennsylvania Carey Law School

Follow this and additional works at: https://scholarship.law.upenn.edu/faculty_scholarship

Part of the American Politics Commons, Bankruptcy Law Commons, Law and Economics Commons, Legal Biography Commons, Legal History Commons, and the Legal Writing and Research Commons

\section{Repository Citation}

Skeel, David A. Jr., "Vern Countryman and the Path of Progressive (and Populist) Bankruptcy Scholarship" (2000). Faculty Scholarship at Penn Law. 1349.

https://scholarship.law.upenn.edu/faculty_scholarship/1349

This Article is brought to you for free and open access by Penn Law: Legal Scholarship Repository. It has been accepted for inclusion in Faculty Scholarship at Penn Law by an authorized administrator of Penn Law: Legal Scholarship Repository. For more information, please contact PennlawIR@law.upenn.edu. 


\title{
VERN COUNTRMMAN AND THE PATH OF PROGRESSIVE (AND POPULIST) BANKRUPTCY SCHOLARSHIP
}

\author{
David A. Skeel, Jr."
}

\section{DNTRODUCTION}

The prominent lawyer and former Yale law professor John Frank tells of Vern Countryman's involvement in the case that eventually became Grissuold $\%$. Connecticut. ${ }^{1}$ In Griswold, as most readers will recall, the Supreme Court struck down a Connecticut statute that prohibited the sale or use of contraceptives. According to Justice Douglas's majority opinion, the statute violated the defendants' constitutional right to privacy. Douglas located this new right not in any specific constitutional provision but in the "penumbra" of several provisions. To challenge the statute, someone had to go out and buy contraceptives. As Frank recounts, Countryman was the one who initially volunteered:

[T]o create a test case, Vern bought some standard contraceptives at a Walgreen's drug store in New Haven. Alas, he discovered that the store was not a great national corporation as he thought; it was simply a franchise operation [that is, Walgreen's stores were run not by Walgreen's itself, but by individuals who managed a particular store under a franchise agreement with Walgreen's] and any charge of illegality would have been against the poor fellow who operated the store. Vern did not want a test case badly enough to victimize an individual and the effort was abandoned. . . .2

To most bankruptcy scholars of recent vintage, Countryman's involvement in one of the most celebrated civil liberties cases of the century would come as a mild surprise. Countryman is remembered as a towering figure in bankruptcy. ${ }^{3}$ (Literally, as well as figuratively: as another prominent friend has noted, "Vern was a big man, tall, and

* Professor of Law, University of Pennsylvania. I am grateful to Bill Draper at the Biddle Law Library of the University of Pennsylvania Law School for help in locating sources and assembling research; to Douglas Baird, Kate Heidt, Eric Posner, and Bob Rasmussen for valuable comments; and to the University of Pennsylvania Law School for generous summer funding.

138 I U.S. 479 (1965).

2 Gerald IS. Smith, Vern Countryman, NORTON BANkr. ADVISER, June 1999, at 2, 5 (quoting John Frank).

3 See, e.g., Nick Ravo, Obituary, Vern Countryman, 81, Professor and Commercial Law Experi, N.Y. TIMES, May i 7 , I999, at Arg. 
with chiseled features and a hard chin." ${ }^{4}$ If bankruptcy scholars playing a word association game were asked what words cane to mind when they thought of Vern Countryman, nearly every one would respond with the same two words: executory contracts. In 1973 , Countryman wrote an article concluding that a contract should be viewed as executory (a designation that has enormous consequences in the technical world of bankruptcy) when the obligations of both parties are "so far unperformed that the fallure by either to complete performance would constitute a material breach." With its characteristic combination of scholarly insight and painstaking doctrinal analysis, the article almost immediately took on a life of its own. Even more remarkable for the mercurial world of bankruptcy scholarship, the article continues to exert influence more than two decades later. Dozens of judicial opinions and numerous law review articles have paid homage to the "Countryman definition" of executory contracts.

If bankruptcy scholars would be mildly surprised to learn that Countryman participated in the Griswold case, then the eyes of many would open still wider (as mine did) on hearing about the not-so-secret events of Countryman's early career. As an assistant professor at Yale Law School in the I950s, Countryman actively and publicly assisted the defendants in several of the loyalty cases brought against individuals suspected of Communist sympathies. ${ }^{8}$ Countryman not only participated in individual cases, he also authored a book and several articles on the loyalty issue. ${ }^{9}$ When Countryman was passed over for tenure at Yale, he and many others believed that his activism in the loyalty cases was the real reason. Undaunted, Countryman remained a fervent activist on civil liberties issues throughout his long career, which included a stint in private practice and the deanship at the University of New Mexico School of Law before he joined the Harvard Law School faculty in 1964 .

Although new bankruptcy scholars might be surprised to learn of Countryman's involvement in civil liberties issues, upon reflection they should find the Griswold anecdote completely in character. The most

4 Smith, supra note 2, at 2 (quoting Professor Charles Alan Wright).

5 Under current law, if a contract is executory, the debtor's trustee may reinstate the contract, even if the debtor defaulted prior to bankruptcy. See iI U.S.C. $\$ 365$ (I994).

6 Vern Countryman, Executory Contracts in Bankruptcy: Part l, 57 MINN. L. REV. 439, 460 (I973).

7 For a vivid example, see Jay Lawrence Westbrook, A Functional Analysis of Executory Contracts, 74 MINN. L. REV. 227, 234-39 (1989).

8 These events are discussed in more detail in Part II.A., infra.

9 See Vern Countryman, Un-American Activities in the State of WAShingTON (I95I). Countryman's articles on loyalty issues include Vern Countryman, The Strange Case of Alger Hiss, 63 YALE L.J. 744 (1954) (book review), and Vern Countryman, Loyalty Tests for Lawyers, I3 LAW. GUILD REV. I 49 (1953) [hereinafter Countryman, Loyalty Tests]. 
telling detail, that Countryman abandoned his mission rather than embroil "the poor fellow who operated the store" in litigation, hints at the overriding theme of Countryman's remarkable career as a bankruptcy scholar. Countryman's passion was to protect the little guy, the individual debtor who had run into financial trouble and filed for bankruptcy. Many of Countryman's articles advocated reforms that would assure greater protection for individual debtors. He fought tirelessly for the interests of debtors in organizations such as the American Bar Association and the National Bankruptcy Conference, and he was a founding trustee of the National Consumer Law Center. For years, the Center has given the "Vern Countryman Award" to "honor lawyers who have contributed to the rights and welfare of lowincome consumers." 10

Countryman is best known for the passion he brought to personal bankruptcy issues, but he also made important contributions - including the "Countryman definition" of executory contracts - in corporate bankruptcy and other areas. To all of these endeavors, he brought the same qualities: a fierce integrity (which included an oftnoted tendency "not to suffer fools gladly" and inspired his classroom nickname during his many years at Harvard, "Stern Vern"11) and an absolute commitment to the correctness of the principles in which he believed. ${ }^{12}$

Vern Countryman's views on bankruptcy and legal issues place him squarely within the progressive tradition in American thought, and it is Countryman's role in progressive bankruptcy scholarship that I focus on in this essay.

The term "progressive" is used throughout the essay in its broad, lay person's sense, to encompass not just the early twentieth century political movement that bears this name, but also American populism, which arose somewhat earlier. ${ }^{13}$ Scholars who identify themselves as "progressive" frequently advocate the use of social data to motivate legislative reform, identify with the socially disadvantaged rather than

10 Ravo, supra note 3 , at Aig.

11 Smith, supra note 2, at 4 (quoting former student Ken Klee).

12 An anecdote concerning Richard Nixon hints at some of these qualities, as well as Countryman's political leanings. After Nixon's reelection, Gerald Smith gave Countryman a bottle of wine from the inauguration. Countryman's initial response was to refuse to drink the wine. As Watergate ran its course, however, the wine took on a new meaning. When Nixon resigned, Countryman called Smith to say he would drink the wine with great pleasure. See Telephone Interview with Gerald Smith, Lewis \& Roca, Phoenix, Ariz. (Feb. 8, 2000).

13 Populism was characterized by a defense of farmers and rural interests, and a hostility toward Wall Street and other concentrations of wealth. Progressivism originated in urban areas and focused on social reform but shared populism's distrust of Wall Street. To distinguish the general term "progressive" from the political movement, I will capitalize references to the Progressive movement. The best account of populism and Progressivism is still RICHARD HOFSTADTER, THE AGE OF REFORM: FROM BRYAN TO F.D.R. (I955). 
the elite, and can be found at the liberal end of the political spectrum on most issues. Although this essay refers more precisely to populism or Progressivism where the distinction is important, the more general term suffices for much of the analysis.

To illustrate the historical sweep of progressive bankruptcy scholarship, the essay begins by briefly describing the work of Countryman's most prominent predecessor, William O. Douglas. Douglas is an obvious choice to represent the origin, roughly seventy years ago, of progressive bankruptcy scholarship. Douglas not only was the intellectual father of progressive bankruptcy scholarship, he also served as Countryman's principal mentor after Countryman clerked with the Justice in the early 1940 s. $^{14}$ For current progressive thinking, the essay explores the work of Elizabeth Warren. Warren is the most prominent current progressive, and - quite conveniently for my chronology - is widely viewed as Countryman's successor as Ilarvard's reigning bankruptcy authority.

In between, of course, came Vern Countryman himself. To lay the groundwork for discussing Countryman's work and his enormous influence, Part I of this essay considers first the progressives who preceded and succeeded him, William Douglas and Elizabeth Warren. The juxtaposition suggests that the concerns of current progressives differ from those of the early scholars in crucial and interesting respects. To see how and why progressive bankruptcy scholarship has evolved, the essay turns to Vern Countryman and his era in Part II. This Part highlights three important differences between Countryman's work and that of Douglas, his mentor: Countryman's emphasis on personal rather than corporate bankruptcy, his close relationship with the bankruptcy bar, and his reaction to the emerging law and economics movement. Part II then shows the continuing prominence of these tendencies in current progressive scholarship. Part III then explores the significance of the shift in perspective for the future of progressive bankruptcy scholarship. ${ }^{15}$

\footnotetext{
14 Having joined the Supreme Court in 1939, Justice Douglas was still in his early years on the Court when Countryman arrived in 1942. Prior to his appointment, Douglas had practiced briefly for the firm of Cravath, Swaine \& Moore in New York, taught at Columbia and Yale Law Schools, and risen to the chair of the Securities and Exchange Commission.

15 I should note at the outset that my own bankruptcy scholarship would not be characterized as progressive. My work fits more neatly within the law-and-economics literature, though I have tried to moonlight as a progressive from time to time. See, e.g., David A. Skeel, Jr., Markets, Courts, and the Brave New World of Bankruptcy Theory, I993 WIS. L. REV. 465, 503-09 (using analysis from Karl Polanyi's 1994 book The Great Transformation to criticize recent law-andeconomics proposals).
} 


\section{BANKRUPTCY PROGRESSIVES THEN AND NOW: DOUGIASAND WARREN}

The origins of progressive bankruptcy scholarship date back to the rise of American legal realism in the late Ig20s and early ig30s. As is well known, the legal realists sought to overthrow the reigning, Langdellian conception of law, and to replace it with a more highly contextual, experimental, "functional" approach.16 In the words of a leading historian of legal realisn, "functionalism ... reflected an atternpt to understand law in terms of its factual context and economic and social consequences." 17

Hard as it is to magine now, in an era when the most hotly contested issues so often come from constitutional law and other public law areas, a disproportionate number of the early legal realists established their reputations in corporate and commercial law. ${ }^{18}$ Among this august company, one academic towers above the rest: William $O$. Douglas. It is no exaggeration to say that, during the decade from roughly I928 to I938, Douglas figured prominently in every significant development affecting bankruptcy law and bankruptcy theory. ${ }^{19}$ After moving from Columbia to Yale in 1928 , as part of the defection that shifted the principal address of legal realism from New York to New Haven, ${ }^{20}$ Douglas embarked on the first important empirical study of

16 In actuality, the origins of legal realism were more complicated than this explanation suggests. For instance, pre-realist Progressives such as Roscoe Pound had already challenged the Langdellian conception when legal realism emerged. For a more nuanced overview of the intellectual history of legal realism, see Thomas C. Grey, Modern American Legal Thought, 106 YALE L.J. 493, 493-508 (I996) (reviewing MEIL DUXBURY, PATTERNS OF AMERICAN JURISPRUDENCE (1995)).

17 LAURA KALMAN, LEGAL REALISM AT YALE: $1927-1960$, at 3 (1986).

18 Underhill Moore, Wesley Siurges, and Karl Llewellyn all specialized in commercial law. See generally id. at 20-35 (describing the early legal realists and their methodology); WILLIAM TWINING, KARL LIEWELLYN AND THE REALIST MOVEMENT I28-40 (r973) (describing Llewellyn's early work on sales law issues). Much of Jerome Frank's early work brought the insights of legal realism to bear on corporate law and corporate reorganization. For illustrations of Frank's remarkable, and resolutely legal realist, insights into corporate bankruptcy, see Jerome Frank, Epithetical Jurisprudence and the Work of the Securities and Exchange Commission in the Administration of Chapter X of the Bankruptcy Act, I8 N.Y.U. L. REV. 3IT (I94I), and Jerome Frank, Some Realistic Reflections on Some Asperis of Corporate Reorganization, I9 VA. L. REV. 54I (1933) [hereinafter, Frank, Some Realistic Reflections]. One of the agendas of this essay is to rekindle academic interest in the bankruptcy scholarship of Douglas, Frank, and other legal realists. A remarkable amount of cutting-edge theory in the recent bankruptcy literature was prefigured by these scholars' writings in the 1930 .

19 Nor was Douglas's influence limited to bankruptcy. He was famously described in the late I 920 as "the outstanding professor of law in the nation." JAMES F. SIMON, INDEPENDENT JOURNEY: THE LIFE OF WILliAM O. DOUGLAS rog (I g80) (quoting a statement attributed to University of Chicago President Robert Hutchins).

20 The resignations of Douglas and several other prominent legal realists were prompted by the appointment of Young B. Smith rather than Herman Oliphant as Dean of Columbia Law School. Robert Hutchins, who was then the Dean of Yale Law School, took the opportunity to 
bankruptcy. Several years later, Joseph Kennedy, the chairman of the Securities and Exchange Commission (SEC), asked Douglas to oversee the SEC's investigation of corporate reorganization practice. Douglas's investigation would inspire major reform in 1938 and would lead Douglas first to the chair of the SEC and then, by I939, to the Supreme Court. ${ }^{21}$

Because Douglas's work played such a dominant role, virtually defining progressive bankruptcy theory in the I930s, his writings are the obvious starting point for my analysis. The first section of this Part therefore provides a brief description and interpretation of Douglas's perspective on personal and corporate bankruptey. The picture that emerges derives both from Douglas's empirical work and theoretical writings and from his interactions with other leading theorists.

The section that follows skips forward in time to the end of the wentieth century and considers current progressive theory. Given that the current theorists are still actively writing, and history has not yet determined whose insights will endure, it is more difficult to select a theorist to complement William Douglas in the progressive line. Several scholars might plausibly be described as characteristic of current progressive bankruptcy theory. Nevertheless, nearly every bankruptcy scholar I know (including myself) would point to Elizabeth Warren's work as most representative of current progressive thinking. ${ }^{22}$ The second section therefore focuses on Warren's contributions to the bankruptcy literature.

Although there are important parallels between Warren's work and Douglas's earlier insights, there also are striking differences. By any measure, late twentieth century progressive bankruptcy theory differs from its antecedents in remarkable respects. Whereas Douglas regularly attacked bankruptcy lawyers, for instance, Warren and other recent progressives are far more sympathetic to the bar. Douglas also

lure Douglas and Underhill Moore to Yale. The best account of these events is KALMAN, supra note $I 7$, at $68-78$.

21 Douglas's SEC career is described in more detail in Part I.A., infra.

22 The most plausible alternative would probably be Lynn LoPucki, who has written widely on corporate and personal bankruptcy and conducted an influential study of large corporate reorganizations with William Whitford. See, e.g., Lynn M. LoPucki \& William C. Whitford, Corporate Governance in the Bankruptcy Reorganization of Large, Publicly Held Companies, I 4I U. PA. L. REV. 669 (I993). Another leading progressive, Jay Westbrook, is a frequent co-author with Warren and therefore also figures prominently in this essay. Moving beyond mainstream progressive bankruptcy scholarship, the most prominent feminist (and communitarian) has been Karen Gross, see KAREN Gross, FAIluRE AND Forgiveness: RebaldANCING THE BANKRUPTCY SYSTEM (I997), and David Carlson at times has brought aspects of postmodernism to bear on bankruptcy theory, see, e.g., David G. Carlson, Philosophy in Bankruptcy, 85 MICH. L. REV. I34I, I389 (I989) (reviewing THOMAS JACKSON, THE LOGIC AND LIMITS OF BANKRUPTCY LAW (I 986)) ("The whole idea of finding a deep structure in a complicated, historical artifact such as the Bankruptcy Code was doomed from the start."). 
was much more hostile than current progressives to managers' efforts to reorganize large corporations.

The differences in perspective raise an obvious question: How did progressive bankruptcy theory move from the concerns of the I930s to the very different concerns of the I9gos? How did progressive theory evolve from William Douglas to Elizabeth Warren? I argue in the next Part that the answer is simple: Vern Countryman. Countryman's work, and the context in which it arose, provides the intellectual link between the insights of the early progressive theorists and those of their recent heirs. Understanding Countryman's influence and his era can teach us a great deal about the path of progressive bankruptcy theory.

\section{A. Knocking Down Idols: William Douglas and Early Progressive Theory}

In an article published some years ago, Steven Winter recounts a famous midrash concerning Abraham, the patriarch of ancient Israel. ${ }^{23}$ Expanding on the biblical account of Abraham's departure from his home country, ultimately to found the nation of Israel, the midrash identifies Abraham's father as having been a maker of idols - wooden or clay statues of false gods. As Abraham grows up, he becomes more and more skeptical about claims that the idols have magical powers until, in a climactic moment, he smashes a row of idols in front of his horrified father.

William Douglas and his fellow legal realists rose to prominence in similar fashion, by smashing the idols of existing legal theory. The principal "idol" was the Langdellian approach perfected at Harvard, which sought to discover fixed, abstract principles in the existing caselaw and to apply these principles in a mechanical fashion to each new case. ${ }^{24}$ Douglas dismissed this approach as "library law." The "so-called case method," he complained, "grossly oversimplifies and distorts the nature of law" by ignoring the "other psychological, political, economic, business, social factors" that influence the law and legal decisionmaking. ${ }^{25}$ Only by adopting an inclusive, contextual, interdisciplinary approach, Douglas insisted, could legal scholars achieve accurate and useful insights about any given issue. It was in his bank-

23 Steven L. Winter, The Cognitive Dimension of the Agon Between Legal Power and Narrative Meaning, 87 MICH. L. REV. 2225, 2226 (Ig8g). The midrashes are a group of Jewish commentaries speculating about aspects of the Hebrew Scriptures. The Biblical account of Abraham occurs in the book of Genesis.

24 For an influential recent analysis of this approach, see Thomas C. Grey, Langdell's Orthodoxy, 45 U. PITT. L. REV. I, I I (I 983).

25 William O. DOUGi.AS, DEMOCRACY AND FinANCE 280 (I940) (quoted with approva! in Jerome Frank, Democracy and Finance, 54 HARV. L. REV. 905, 908 (r94 I) (book review)). 
ruptcy scholarship that Douglas sought most fully to put these commitments into practice.

Bankruptcy law as Douglas found it looked quite different from the insolvency framework that we now have. Under current law, almost every bankruptcy involving an individual, partnership, or corporation is included within a single statute. In the late I920s, by contrast, bankruptcy law was divided into two very different legal regimes, one for small debtors and the other for large-scale corporate reorganization. If an individual or small business encountered financial difficulties, it invoked the first of these regimes, the Bankruptcy Act of 1898 , which was the nation's first permanent bankruptcy law. ${ }^{26}$ Under the relatively simple procedures of the I 898 Act, an individual who filed for bankruptcy would turn over his assets to the bankruptcy court, and a trustee would then sell the assets for the benefit of the debtor's creditors. Then, as now, individual debtors were not required to give up all of their assets, however. Under the laws of each state, certain kinds of property were exempt and thus unavailable to creditors; the list usually included items like household goods and property that were essential to a debtor's livelihood. The I898 Act permitted debtors to exempt any property that was protected by the exemption laws of the debtor's state. In return for giving up his nonexempt assets, the debtor received a discharge from his existing obligations - that is, the existing debts were voided. ${ }^{27}$ In its original incarnation, the 1898 Act did not offer a rehabilitation option designed for individuals. Not until the I930s did bankruptcy law give debtors a choice between straight liquidation and proposing a rehabilitation plan.

The 1898 Act contemplated that, as with individual debtors, most business debtors would have their assets liquidated and then distributed to creditors. The 1898 Act did provide a limited reorganization option. Under the Act's "composition" provision, a business debtor could restructure its unsecured debt - obligations that were not collateralized by some or all of the firm's property - if a majority of unsecured creditors voted to accept the restructuring. ${ }^{28}$ This provision

26 Act of July I, I 898 , ch. 54 I, 30 Stat. 544 (1899). For a detailed account of the political origins of the 1898 Act and the reasons that it survived, see David A. Skeel, Jr., The Genius of the I898 Bankruptcy Act, 15 BANkR. DEV. J. 32 I (I999). Provisions of the current Bankruptcy Code, Act of Nov. 6, 1978, Pub. L. No. 95-598, 92 Stat. 2549 (codified as amended at I I U.S.C. $\$ \$$ IOI-I330 (I994)), which was enacted in I978, will be cited hereafter as sections of the "Bankruptcy Code." Provisions of the Bankruptcy Act of 1898 will be cited as sections of the "Bankruptcy Act."

27 In addition to exemptions and the discharge, a third crucial feature of personal bankruptcy was and is the trustee's preference powers. To prevent some creditors from enjoying special treatment, bankruptcy's preference provisions permit the trustee to retrieve payments and other transfers made to creditors shortly before bankruptcy. See Bankruptcy Act $\$ 60$.

28 See Bankruptcy Act \$ 12 . 
was almost useless for large corporate debtors, however, because the principal obligations of railroads and other large corporations were secured, as noted below, and the Act did not allow restructuring of secured debt. Even for small corporations, the value of the reorganization option was limited. ${ }^{29}$ The assets of most bankrupt businesses like the assets of individual debtors - were simply liquidated.

Well before the I $898 \mathrm{Act}$, Wall Street investment bankers and their lawyers had created a very different regime for addressing the financial distress of large corporations, which, in the nineteenth century, usually were railroads. When numerous railroads failed in the nineteenth century, the bankers and their lawyers persuaded courts to restructure the railroads through a device that became known as an "equity receivership." 30 Most large railroads had raised cash by selling stock and one or more classes of mortgage bonds - obligations that were secured by property of the railroad - to numerous outside, or "public," investors. If the railroad defaulted, a friendly creditor (usually one whom the managers themselves had handpicked) would put the railroad into receivership and ask that the firm's assets be sold in a foreclosure sale. Meanwhile, the banks that had served as the railroad's underwriters when a class of stock or bonds was first sold would form a committee - called a "protective committee" - to negotiate on behalf of the widely scattered investors who held that class of securities. To establish a committee, the banks that had sold the stocks or bonds would ask investors to "deposit" their securities with the incipient committee. An investor who agreed to this arrangement signed a deposit agreement that gave the committee the right to accept or reject a proposed restructuring plan on her behalf. ${ }^{31}$ Once the committees were in place, their representatives negotiated the terms of the restructuring with the railroad's managers. The firm was then reorganized through a "sale" to its existing creditors. In reality, the "sale"

29 The composition provision also required that the debtor make its priority payments in cash at the time the reorganization was confirmed. See H.R. REP. NO. 75-1409, at 48-49 (I937). Small corporations found satisfying this requirement difficult.

30 The emergence of the equity receivership procedure to reorganize the nation's first large corporations that failed, the railroads, is one of the great stories of American legal ingenuity. I have described the history in detail elsewhere. See David A. Skeel, Jr., An Evolutionary Theory of Corporate Law and Corporate Banknptcy, 5I VAND. L. REV. I325, I353-58 (I998). For an extensive overview of the receivership process by a leader of the reorganization bar, see Paul D. Cravath, The Reorganization of Corporations: Bondholders' and Stockholders' Protective Committees; Reorganization Committees; and the Voluntary Recapitalization of Corporations, in SOME LEGAL PHASES OF CORPORATE FINANCING, REORGANIZATION AND REGULATION I53 ( 1917 ).

31 In theory, anyone could form a stockholder or bondholder committee. Although outsiders sometimes established competing committees, the underwriter for the securities had an enormous advantage because it already had a list of all the investors. 
simply reflected the terms to which the parties had agreed in their negotiations.

By the end of the nineteenth century, the same Wall Street professionals who dominated the issuance of securities to public investors J.P. Morgan and Company, Kuhn, Loeb, and Company, and a small group of other investment banks, together with their attorneys - were also the principal players in nearly every major reorganization. As I describe below, this Wall Street hegemony triggered a sharp backlash in the I930s. For present purposes, the important point is that largescale reorganization developed in the courts, entirely outside the confines of the 1898 Bankruptcy Act.

Douglas's work took him deeply into both the general bankruptcy practice governed by the 1898 Act and large-scale reorganization. His first major project, which he began in 1928 , focused on bankruptcies arising under the 1898 Act and illustrated the realists' preoccupation with empirical investigations. ${ }^{32}$ Douglas complained that, although it was obvious that many different factors contributed to financial distress, most observers were "content to leave the problem there." 33 Douglas decried this passivity as inadequate and outmoded. "[T]hose who are interested in social reform and those who are interested in problems of social causation," he insisted, must "go further." 34 By "tracing the social, economic and legal antecedents, and by estimating the causal processes," investigators could produce "results of tremendous practical and scientific significance." 35

To remedy the lack of empirical data on bankruptcy, Douglas embarked on a remarkable study of bankruptcy cases filed in New Jersey from I929 to I930 and in Boston from I930 to I93 I.36 Working with bankruptcy and district court judges, as well as the Department of Commerce, Douglas and his researchers conducted extensive interviews with hundreds of debtors and assembled case files on a total of I 500 bankruptcies. Based on this data, Douglas explored a wide range

32 For an extensive history of legal realist empiricism and an excellent, often critical discussion of Douglas's bankruptcy study, see John Henry Schlegel, American Legal Realism and Empirical Social Science: From the Yale Experience, 28 BUFF. L. REV. 459 (I979).

33 William Clark, William O. Douglas \& Dorothy S. Thomas, The Business Failures Project - A Problem in Methodology, 39 YALE L.J. ror3, ror3 (1930).

34 Id.

$35 \mathrm{Id}$.

36 The articles that emerged from this project include Clark, Douglas \& Thomas, supra note 33; William O. Douglas \& Dorothy S. Thomas, The Business Failures Project - II. An Analysis of Methods of Investigation, 40 YALE L.J. I034 (I93I); William O. Douglas \& J. Howard Marshall, A Factual Study of Bankruptcy Administration and Some Suggestions, 32 COLUM. L. REV. 25 (I932); William O. Douglas, Some Functional Aspects of Bankniptcy, 4I YALE L.J. 329 (I932) [hereinafter Douglas, Some Functional Aspects]; and William O. Douglas, Wage Eamer Bankmptcies - State vs. Federal Control, 42 YALE L.J. 59I (I933) [hereinafter Douglas, Wage Earner Bankruptcies]. 
of issues, including the quality of accounting records kept by small businesses that failed and the relationship between automobile accident judgments, gambling, or extravagant expenditures and bankruptcy filings. ${ }^{37}$

The conclusions that Douglas drew from his study reveal a remarkably thoughtful vision of the proper role of bankruptcy reform one that cannot be described as simply "pro-debtor" or "pro-creditor."38 The common theme in Douglas's findings is an assumption that bankruptcy should be designed to promote self-reliance and industry, and should provide a second chance for debtors who fail for reasons they could not easily have controlled. Douglas worried that creditors' excessive lending mizht be a contributing factor in the failures of some, or even many, debtors. "There is . . a considerable body of opinion," he noted, "which traces [bankruptcy problems] to the ease with which the debtor gets credit." 39 Debtors' right to file for bankruptcy and request a discharge was an important corrective to such inappropriate credit practices. At the same time, Douglas strongly believed that many debtors could avoid financial distress if they were encouraged to manage their affairs more carefully. Several of Douglas's proposals sought, in overtly instrumental fashion, to shape future debtors' behavior. For example, Douglas argued that courts should encourage businesses to keep adequate accounting records by refusing to discharge debtors that did not. ${ }^{40}$ Similar limitations might induce more debtors to obtain adequate automobile insurance, and to avoid gambling and excessive speculation..$^{41}$

Instead of devising clear rules to achieve these goals, Douglas, like many legal realists, was a fervent advocate of judicial and administrative discretion. In his discussion of speculation and gambling, for instance, Douglas insisted: "[An] attempt to treat all cases of speculation and gambling categorically would be absurd. It would seem desirable, however, to provide administrators with discretionary power so as to

37 As this overview suggests, the study was enormously detailed and thus rather intrusive for the debtors involved (who were under substantial pressure to respond because the study bore the imprimatur of the judge). Douglas's biographer suggests that the methods "would have been onerous to the future Justice Douglas, who defined the constitutional right of privacy." SIMON, supra note i9, at II3.

38 For an argument that Douglas's theoretical conclusions were only loosely tied to his empirical findings, see Schlegel, supra note 32, at 530-31. Schlegel argues that Douglas and other early legal realists faced a tension between their commitment to empiricism and their desire to achieve immediate social reform. On this view, Douglas abandoned his empiricism in order to pursue social change.

39 William O. Douglas, Bankruptcy, in ENCYClOPAEDIA OF THE SOCIAL SCIENCES 449 , 453 (Edwin R.A. Seligman ed., I937).

40 See, e.g., Douglas, Some Functional Aspects, supra note 36, at 338-39.

41 See id. at 343 (automobile judgments); id. at 346-47 (speculation and gambling). Douglas included stock speculation within his definition of inappropriate risk taking. 
take cognizance of the variants among the cases." ${ }^{42}$ The principal inspiration for Douglas's preferred approach was English bankruptcy law. ${ }^{43}$ Unlike the U.S. law, which contemplated that courts would grant (or on rare occasions, deny) a debtor's discharge shortly after he filed for bankruptcy, the English approach gave the decisionmaker far more discretion. In England, the decisionmaker could delay or impose conditions on the discharge rather than give an immediate thumbs up or thumbs down - an option English officials exercised more than ninety percent of the time. ${ }^{44}$ The great virtue of adopting a flexible approach to discharge, Douglas argued, was that it would enable the decisionmaker to create a solution tailored to the circumstances and needs of the particular debtor. ${ }^{45}$

Underlying all of Douglas's views was the conviction that lawmakers should "experiment" and consider radical change where necessary. This commitment to experimental reform brought Douglas into direct conflict with bankruptcy professionals and the bankruptcy bar. Douglas clearly reveled in this role. Speaking to a large group of bankruptcy judges ${ }^{46}$ in 1932 , he threw down the gauntlet, saying, "in the immobility of vested interests I have disrespect; and in the lethargy and timidity against experimentation I have utter contempt." ${ }^{4}$ In this most inhospitable of venues, Douglas vigorously defended a new bankruptcy bill, ${ }^{48}$ based largely on English bankruptcy law, that would re-

42 Id. at 347

43 See id. at 332-33 ("Exemplary of an administrative flexibility, lacking in our system, are the following discharge provisions of the Bankruptcy Act of England ...."); Douglas \& Marshall, supra note 36 , at $35-37$.

44 This percentage is determined from statistics quoted by Douglas. See Douglas, Some Functional Aspects, supra note 36 , at 334. The English approach dates back to 1883 and continues to characterize English bankruptcy law today. For a more recent discussion of England's discretionary discharge, see Douglas G. Boshkoff, Limited, Conditional, and Suspended Discharges in Anglo-American Bankmptcy Proceedings, I3 I U. PA. L. REV. 69 (I982).

45 See Douglas, Some Functional Aspects, supra note 36, at 363-64 (summarizing proposals for discretionary discharge). In contrast to his faith that a court or administrator could impose appropriate conditions on a debtor's discharge, Douglas was less sanguine about rehabilitation plans proposed by the debtors themselves. Douglas worried that "wage earners may well be under pressure of creditors to [propose a rehabilitation plan rather than seek an immediate discharge]; and [debtors'] excessive optimism may well lead to attempts to do so." Douglas, Wage Earner Bankruptcies, supra note 36, at 631. Douglas had previously been sympathetic to wage earner plans, see Douglas \& Marshall, supra note 36, at 49-56 (recommending that wage earner plans be allowed as long as they were strictly voluntary), but he apparently had become more skeptical by 1933, when Wage Earner Bankruptcies was published.

46 Bankruptcy judges were called "referees" until 1973. For simplicity, I will refer to them as "judges" throughout the essay.

47 William O. Douglas, The Hastings Bill and Lessons Learned from the Bankruptcy Studies, 7 J. NAT'L ASS'N REF. BANKR. 25, 25 (i932).

48 The bill — called the "Hastings Bill" — was inspired by the Donovan Report, William J. Donovan, Report of Counsel to the Petitioners, In re Inquiry into the Administration of Bankrupts' Estates (S.D.N.Y. I930), reprinted in ASS'N OF THE BAR OF THE CITY OF N.Y., IN RE 
place many of the judicial aspects of U.S. bankruptcy with a more administrative approach. ${ }^{49}$

Douglas showed no sympathy whatsoever for bankruptcy lawyers' and judges' argument that sweeping change would unsettle more than thirty years of established practice. He told the judges:

I cannot agree with the philosophy of the distinguished committee of the American Bar Association when it says that upon the present Bankruptcy Act 'has been builded a great body of judicial decisions which must not be destroyed or abandoned in favor of theoretical or untested innovations.'

[W] hat commentary is it on the legal profession that we may follow our ancient habits with so much unconcern in face of the advancement of our knowledge in recent years? Do, [sic] we want to treat all bankrupts alike? Are we not interested in whence they come and whither they are going?50

Despite Douglas's efforts, the bankruptcy bar managed to fend off the administrative reforms. By the end of 1932, the Depression had deepened, and legislators became more concerned about relief for personal and corporate debtors than about overhauling the system altogether. Congress did enact significant legislation, but it merely codified and expanded existing practice..$^{51}$

Having conducted a painstaking study of individual and small business bankruptcy, Douglas next turned to the other area of insolvency law - the reorganization of large corporations. In 1934, he wrote an important article arguing for a balance between governmental oversight and private negotiation in railroad reorganization. ${ }^{52}$

ADMINISTRATION OF BANKRUPT ESTATES (1930), and the Thacher Report, S. DOC. NO. 72-65 (1932), which called for sweeping bankruptcy reform after investigations of existing practice. Douglas participated in the Donovan and Thacher investigations, and both made use of his bankruptcy studies.

49 See Douglas, supra note 47 , at 25-26. In addition to defending the proposed shift to an administrative approach, Douglas suggested an even more radical experiment: "Why not abolish this terrifying Federal beaurocracy [sic] [that is, the proposed administrative agency] and return the power [to regulate bankruptcy] to the states?" Id. at 27 . Douglas defended his provocative proposal to let the states regulate personal bankruptcy - a proposal that deserves far more attention than it has been given by subsequent scholars - at length in an article he published the same year. See Douglas, Wage Earner Bankruptcies, supra note 36.

50 Douglas, supra note 47 , at 26.

51 Congress codified railroad receivership and provided for small debtor and farmer rehabilitation plans in 1933 , and codified corporate reorganization (that is, receiverships of large, nonrailroad firms) in 1934 . The most important effect of the 1933 and 1934 reforms was to include large-scale corporate and railroad reorganization within the Bankruptcy Act for the first time. For a description and political analysis of these reforms, see Skeel, supra note 30, at 1 362-68.

52 See William O. Douglas, Protective Committees in Railroad Reorganizations, 47 HARV. L. REV. 565 (I934). Douglas had also conducted a small, earlier study of equity receiverships in Connecticut. See William O. Douglas \& John H. Weir, Equity Receiverships in the United States District Court for Connecticut: 1920-1929, 4 CONN. B. J. I (1930). Interestingly, the firms in 
Douglas advocated a greater governmental role in policing protective committee negotiations but rejected an earlier proposal (by another ardent New Dealer) for more sweeping governmental control.53

In the same year, Congress enacted legislation instructing the Securities and Exchange Commission to conduct a study of large corporate reorganizations. ${ }^{54}$ That fall, James Landis contacted Douglas at the behest of Joseph Kennedy, the first chair of the SEC, and asked Douglas if he would come to Washington to conduct the study. ${ }^{55}$ Douglas accepted, and he spent the next several years overseeing a massive investigation of corporate reorganization practice. With an equally monumental report, Douglas articulated a distinctively progressive vision for large-scale reorganization, later reflected in the legislation that it inspired. 56

Douglas's strategy for investigating corporate reorganization echoed the approach of his earlier bankruptcy study in important respects, but on an even larger scale. Douglas and his principal assistant, Abe Fortas (a Douglas protégé who would later join Douglas on the Supreme Court), ${ }^{57}$ developed an extensive questionnaire to give to the bankers and lawyers involved in every significant restructuring case in the country. Fortas and other members of the SEC staff, and occasionally Douglas himself, then crisscrossed the country conducting interviews. They were appalled by what they found. Because firms' old managers usually remained in control, and because firms' bankers and lawyers were allied with them, no one had any incentive to investigate the possibility that the managers had engaged in fraud or mismanage-

Douglas's Connecticut study were mid-sized rather than truly large scale, and his study reflected much less hostility than his subsequent work on corporate reorganization would.

Throughout this period, Douglas had written a series of important articles on corporate and securities law. See, e.g., William O. Douglas \& George E. Bates, Some Effects of the Securities Act upon Investment Banking, I U. CHI. L. REV. 283 (I933); William O. Douglas, A Functional Approach to the Law of Business Associations, 23 ILL. L. REV. 673 (1929).

53 See Max Lowenthal, The Railroad Reorganization Act, 47 HARV. L. REV. I8 (1933).

54 See Securities Exchange Act of 1934, Pub. L. No. 73-29I, \$2 I I, 48 Stat. 88I, 909 (codified at 15 U.S.C. $\$ 78$ (1994)).

55 See SIMON, supra note 19 , at I35; James Allen, Introduction, in DOUGLAS, supra note 25 , at $\mathrm{x}$ (quoting TME, Oct. I I, I937).

56 The report, SECURITIES AND EXCH. COMM'N, REPORT ON THE STUDY AND INVESTIGATION OF THE WORK, ACTIVITIES, PERSONNEL AND FunCtIONS OF PROTEC'TIVE AND REORGANIZATION COMMTTEES (I936-1940) [hereinafter SEC REPORT], ultimately grew to eight volumes. Douglas later speculated that Vern Countryman was the only person outside the SEC who ever read the entire report. See SIMON, supra note I9, at 149 (noting that even Countryman did not read the report "for bedtime reading but to prepare for his judicial clerkship with Douglas").

57 As Douglas began the study, Fortas was already working for Douglas's friend Jerome Frank at the Agricultural Adjustment Administration. As recounted by Douglas's biographer, "[w]hat soon transpired was an extraordinary exchange of letters between Douglas and Frank, in which Douglas, with an impressive combination of audacity, good humor and persistence, wrenched Fortas away from his protesting employer." SIMON, supra note 19, at I4I. 
ment.58 Moreover, the Wall Street professionals who organized protective committees in order to negotiate the reorganization seemed to focus more on obtaining generous fees for themselves than on striking a good bargain on behalf of the scattered investors whom they purported to represent. 59 The big losers, of course, were small, individual investors. 60

To remedy these problems, the SEC recommended sweeping changes. To ensure an objective assessment of management, the SEC proposed replacing the managers with an independent trustee in every large reorganization case. ${ }^{61}$ The independent trustee would be authorized to run the debtor's business during the case and would develop a proposed reorganization plan. To eliminate conflicts of interest, the SEC proposed to prohibit any banker or lawyer that had a preexisting relationship with the troubled firm from serving either as trustee or as the trustee's attorney. ${ }^{62}$ The proposals also would prohibit the parties from soliciting votes on a proposed reorganization plan until after a court approved the plan. ${ }^{63}$ The overall effect of these proposals would be to shift the focus of reorganization to the independent trustee and his professionals, and to usher the central play-

58 Concerning bankers and managers, the report complained:

Managements and bankers seek perpetuation of [their] control for the business patron age it commands, which they may take for themselves or allot to others, as they will They seek, also, to perpetuate that control in order to stifle careful scrutiny of the past history of the corporation. Thereby, claims based on fraud or mismanagement are stilled ...

Id. at 863

59 Concerning reorganization lawyers, the report stated:

[C]ounsel fees frequently constitute the largest single item on the list of reorganization fees. . . The vice is that the bar has been charging all that the traffic will bear. It has forsaken the tradition that its members are officers of the court and should request and expect only modest fees.

I SEC REPORT, supra note 56 , at 867

60 Progressive scholars had been raising these complaints for years by the time Douglas and his staff completed the SEC Report. Most prominently, Max Lowenthal wrote a book-length expose of the reorganization of the Chicago, Milwaukee \& St. Paul Railroad (the "St. Paul") that decried the domination of the process by the Wall Street bankers and bar. See MAX LOWENTHAL, THE INVESTOR PAYS (I933). Interestingly, Douglas himself had worked extensively on the St. Paul case during his brief career as a practicing lawyer at Cravath, Swaine \& Moore. See Simon, supra note i 9 , at $84-85$.

61 The mandatory trustee requirement was by far the most controversial of the SEC proposals. For a more detailed discussion of the proposals and the legislative history, see David A. Skeel, Jr, The Rise and Fall of the SEC in Bankruptcy (Nov. 9, 1999) (unpublished manuscript, on file with the author).

62 Under the SEC proposals (and, after their enactment in the Chandler Act amendments of 1938, under the Bankruptcy Act), both the trustee and the trustee's attorney were required to be "disinterested." Amendments to the Bankruptcy Act of 1898 , Act of June 22, I 938, ch. $575, \$$ I 56 , 52 Stat. 840,888 (trustee); id. at $\$ r_{57}, 52$ Stat. at 888 (trustee's attorney). "Disinterested" was defined explicitly to exclude any underwriter of outstanding securities, and any attorney for the debtor or its banks. See id. at $\S 158,52$ Stat. at 888 .

63 See id. at $\S 176,52$ Stat. at 891 . 
ers under existing law - managers, Wall Street bankers, and Wall Street lawyers - out of the reorganization process altogether. For the debtors' managers and their professionals, filing for bankruptcy would mean turning over the keys to the SEC, the court, and a trustee.

As with the general bankruptcy bar in his earlier study, Douglas did not hesitate to attack the reorganization bar (and by implication, Cravath, his former employer and the leading reorganization firm):

The prominence of the lawyer extends down to the close of reorganization and includes the negotiation and consummation of a plan of reorganization... [A]t times the client has abdicated, so to speak, leaving the lawyer in sole command.... [T] tions. Conflicts of interest have had their corroding influence. ${ }^{6+}$

Abe Fortas's account to Douglas of a visit to Fortas's Yale Law School reorganization class by Robert Swaine of Cravath, the nation's most prominent reorganization lawyer, illustrates the depth of the hostility that the SEC report aroused. "Approximately an hour and a half was taken up with a defense of himself and an attack of Part I of our report," Fortas reported. "[Swaine] assured the boys that Part I designated him as a liar and a perjurer; he pointed out the many sections in which, according to his interpretation, he was accused of avarice. He entered a most vigorous denial to all the charges." 65

As in his work on small bankruptcies, Douglas insisted on the need for experimentation and sweeping change. Once again, his emphasis was on the importance of the individual: this time, the small investors in large, troubled firms. Only by displacing a debtor's managers with an independent trustee, and wresting control of reorganization away from Wall Street, could investors' interests be truly protected. In the middle of the New Deal, with the weight of the SEC behind him and populist antagonism toward Wall Street professionals at high tide, Douglas was perfectly positioned to convert the SEC experiment in investor protection into federal law. ${ }^{66}$ In 1937 , the SEC injected its proposals into bankruptcy legislation that had been pending in Congress

64 Douglas, supra note 25, at 233. During the SEC investigation, Douglas interrogated all of the most prominent reorganization lawyers. In his often apocryphal autobiography, Douglas claimed that after he finished deposing Robert Swaine, his former boss at Cravath, Swaine marveled that Douglas "stood me on my head and shook all of the fillings out of my teeth." William O. DOUGlas, Go EAST YOUNG MAN: ThE EARly YEARS 260 (r974) [hereinafter, DOUGLAS, GOEAST].

65 Letter from Abe Fortas to William O. Douglas (May 20, 1937) (on file with the Library of Congress, Douglas Papers, Container No. 6).

66 By late 1937 Douglas had become Chairman of the SEC and had launched a stunningly successful effort to reorganize the New York Stock Exchange to better serve investors' interests. $\mathrm{He}$ also had become a close advisor to President Roosevelt by this time. See SIMON, supra note I 9 , at I68-75. These developments obviously did not hurt his influence in the bankruptcy reform process. 
for several years. Congress subsequently enacted the proposals, almost verbatim, as Chapter $\mathrm{X}$ of the Chandler Act of 1938.67

To put William Douglas's bankruptcy legacy into broader context, it is important to note that other prominent scholars had differing perspectives regarding what a progressive bankruptcy framework should look like. For personal and small business bankruptcy, several of Douglas's colleagues at Yale proposed different and arguably more dramatic, though related, reforms. Most intriguing was Wesley Sturges's call to revamp the commercial law priority framework. Under Sturges's proposal, earlier creditors would take priority over subseguent ones, so that a subsequent creditor ran the risk of being left with nothing if it lent to an overburdened debtor. ${ }^{63}$

On corporate bankruptcy, progressive scholars divided along the same lines as did New Deal theorists in a famous economic debate during the Roosevelt Administration. 69 Advocates of "competition" like Louis Brandeis wanted to destroy big business in order to protect local entrepreneurs; they favored Main Street over Wall Street. ${ }^{70}$ The "planners," by contrast, led by Rexford Tugwell and Adolf Berle of Roosevelt's "brain trust," argued that the consolidation of business and the growth of the giant corporations were inevitable. Rather than fragmenting business, therefore, the planners wanted to subject it to pervasive governmental control. ${ }^{71}$

Douglas shared Brandeis's emphasis on competition and individual initiative, and was sometimes chided by "planners" such as Jerome Frank for not advocating greater governmental oversight. ${ }^{72}$ Douglas's

67 Act of June 22, I 938, ch. 575, 52 Stat. 840, repealed by Pub. L. No. 95-598, 92 Stat. 2549, 2682 (1978). Prior to the SEC's involvement, the Chandler Bill had consisted of extensive changes proposed by the National Bankruptcy Conference (NBC), an organization that included the leading members of the bankruptcy bar. The SEC dramatically intervened in late 1936, proposing an entirely new set of provisions for the reorganization of large corporations. The Chandler Act reflected a tense alliance between the SEC and the NBC, with the SEC dictating the terms of large corporate reorganizations ("Chapter X") and the NBC influencing the remainder of the Act. For a more detailed discussion, see Skeel, supra note 30, at I368-72.

68 See Wesley A. Sturges, A Proposed State Collection Act, 43 YALE L.J. I055 (1934); Wesley A. Sturges \& Don E. Cooper, Credit Administration and Wage Earner Bankruptcies, 42 YALE L.J. 487 (1933). Although he thought that Sturges's proposal had limitations, Vern Countryman later discussed it with obvious approval. See Vern Countryman, Improvident Credit Extension: A New Legal Concept Aborning?, 27 ME. L. REV. I, 6-8 (1975).

69 For a good overview of this debate, see ARTHUR M. SCHLESINGER, JR., THE CRISIS OF THE OLD ORDER: I 9 I 9-1933, at 398-405 ( 1957 ).

70 Brandeis's views were best known from his famous book excoriating the "Money Trust." LOUIS D. BRANDEIS, OTHER PEOPLE'S MONEY 5 (Igr4).

71 See SCHLESINGER, supra note 69, at 399-405.

72 Commenting on Douglas's suggestion in his railroad reorganization article that the parties rather than a government agency should develop the terms of reorganization, Frank responded:

I am not thoroughly convinced that the technique you advocate is the best one. If the [Interstate Commerce] Commission has too many duties to permit it to undertake, on its 
SEC proposals called for much more aggressive reform than he had advocated earlier, and can be seen as responding in part to these criticisms. Yet as radical as the SEC proposals were, they nevertheless assumed that private parties (principally the independent trustee) would run the reorganization process. Douglas's vision for progressive reform meant breaking the grip of the Wall Street bankers and lawyers and protecting investors - not direct governmental control.

Even after joining the Supreme Court in 1939, Douglas pursued his progressive approach to bankruptcy. In two early opinions, Douglas held that the Chandler Act and the corporate reorganization provision it replaced prohibited confirmation of a reorganization plan unless it complied with the absolute priority rule. ${ }^{73}$ Under the absolute priority rule, lower priority creditors and stockholders cannot receive anything in a reorganization unless senior creditors are paid in full. ${ }^{74}$ Whereas the reorganization bar had long insisted that flexible priority rules were essential to the reorganization process, ${ }^{75}$ Douglas and other progressive scholars believed that strict enforcement of the parties' priorities provided crucial protection for junior creditors. ${ }^{76}$ Absent absolute priority, senior creditors and shareholders could enter into collusive arrangements that preserved an interest for shareholders at the expense of junior creditors. ${ }^{i 7}$ By construing ambiguous language that appeared both in the 1938 Chandler Act amendments and in prior law as

own, the formation of a Plan, then it seems to me some agency or agencies should be set up with all the powers that you advocate.

Letter from Jerome Frank to William O. Douglas (Jan. 19, 1934) (on file with the Library of Congress, Douglas Papers, Container No. 6).

73 See Consolidated Rock Prods. Co. v. DuBois, 3 I 2 U.S. 5 IO, 527 (I94I); Case v. Los Angeles Lumber Prods. Co., 308 U.S. I06, ing (1 939).

74 For a detailed discussion of the absolute priority rule and its history, highlighting the roles of Douglas, Jerome Frank, and Robert Swaine, see Douglas Baird \& Robert K. Rasmussen, Boyd's Legacy and Blackstone's Ghost (Dec. Io, I999) (unpublished manuscript, on file with the Harvard Law Review).

75 See Robert T. Swaine, Reorganization of Corporations: Certain Developments of the Last Decade, 27 COLUM. L. REV. 90I, 9II-23 (I927). Among other things, flexible priority rules, which became known as "relative priority," permitted shareholders to participate rather than have their interests cut off in favor of higher priority creditors. Shareholders often were an important source of new capital, and because the firm's managers often held stock, relative priority also gave them an incentive to facilitate the reorganization process rather than to resist it.

76 See Frank, Some Realistic Reflections, supra note I8, at 566-69.

77 The collusion could take a variety of forms. Senior creditors might agree to a restructuring pursuant to which the old sharcholders acquire the firm at the foreclosure sale in return for a cash contribution, but junior creditors receive neither the right to contribute nor any payment. The risk to junior creditors was magnified by the artificial nature of the sale. Because outside bidders rarely appeared, managers and senior creditors had significant flexibility in valuing the firm's assets. See Baird \& Rasmussen, supra note 74, at I4-I 7; Frank, Some Realistic Reflections, supra note 18 , at 553-55. 
adopting a firm commitment to absolute priority, ${ }^{78}$ Douglas reinforced the progressive vision of corporate reorganization that Congress had enacted in $1938.7^{79}$

\section{B. Progressive Bankruptcy Theory Today: Elizabeth Warren}

Sixty years after Douglas joined the Supreme Court, scholars continue to debate many of the same issues that preoccupied him and other progressives in the I930s. Foremost among the current progressives is Elizabeth Warren. Like Douglas, Warren decries the dearth of empirical data and insists on the need both to fill this gap and to use empirical work to inform an agenda for constructive change. In words that echo Douglas's approach, she proclaims that "a debate without data is a useless excursion, a trip from nowhere to nowhere." 80 As similar as Warren's commitments are to those of Douglas and the early progressives, they also differ in intriguing respects. ${ }^{81}$

Elizabeth Warren is best known for an extensive study of personal bankruptcy that she conducted with Theresa Sullivan and Jay Westbrook, which led to their 1989 book As We Forgive Our Debtors. ${ }^{82}$ Since William Douglas's landmark investigation of small business and personal bankruptcy in the I930s, there had been only a few largescale empirical efforts to investigate personal bankruptcy. The most influential of these was a Brookings Institute study that figured prominently in the debates that led to the 1978 Bankruptcy Code. ${ }^{83}$ Warren and her co-authors embarked on an even more extensive study, in their words "the largest study of consumer debtors undertaken in

78 The amendments required that a reorganization plan be "fair and equitable." Chandler Act of I 938 , ch. $575, \S 22$ I(2), 52 Stat. 840,897 (codified as amended at I I U.S.C. $\$$ I I 29 (b)(I) (I 994)). Douglas treated this language as a shorthand reference to the absolute priority rule.

79 The progressives were not the only scholars writing about bankruptcy law, of course. Other scholars, the most prominent of whom was James McLaughlin of Harvard, wrote in the doctrinalist tradition. Along with a small group of bankruptcy lawyers and academics, McLaughlin helped to found the National Bankruptcy Conference in I932. He was the leading doctrinal scholar, and a fixture at congressional hearings on bankruptcy from the I920s to the I960s. For an illustrative early article, see James A. McLaughlin, Amendment of the Bankruptcy Act, 40 HARV. L. REV. 34I (I927). Although the interests of these scholars and Douglas's SEC intersected briefly in their combined efforts to promote bankruptcy reform in 1938 , the progressives and doctrinalists otherwise had little in common. The doctrinalists were traditional and conservative, whereas the progressives took a passionate interest in experimentation and change.

80 Elizabeth Warren \& Jay Lawrence Westbrook, Searching for Reorganization Realities, 72 WASH. U. L.Q. I 257 , I 258 (I994).

81 In addition to the distinctions that $I$ note in the text, Warren can be seen as populist in orientation, whereas Douglas's views have more in common with the Progressive movement.

82 Teresa A. SUllivan, Elizabeth WARren \& JAY LAWrence Westbrook, AS We Forgive OUR DEBTORS: BANKRUPTCY AND CONSUMER CREDIT IN AMERICA (1989).

83 David T. Stanley \& Marjorie Girth, Bankruptcy: Problem, Process, ReFORM (1971). 
the United States." 84 Based on the information that debtors must provide when they file for bankruptcy, Warren and her co-authors studied a total of 1,547 cases filed in I98I in ten districts scattered throughout Texas, Pennsylvania, and Illinois. ${ }^{85}$

In As We Forgive Our Debtors, Sullivan, Warren, and Westbrook provide a detailed profile of U.S. bankruptcy debtors and their financial condition when they filed for bankruptcy. Some of the authors' findings are unsurprising: for example, individuals who file for bankruptcy in this country tend to have more debt and less income than those who do not. ${ }^{86}$ Less obvious is the study's finding that debtors do not come disproportionately from low-pay, low-prestige occupations. To the contrary, debtors look much like everyone else, suggesting that layoffs or other job disruptions may be the principal reason for their much lower income. ${ }^{87}$

Throughout their analysis, Warren and her co-authors pay particular attention to issues involving debtors' decisions whether to seek an immediate discharge under Chapter 7 of the Bankruptcy Code or to propose a three- to five-year rehabilitation plan under Chapter $13{ }^{88}$ Commentators and creditor groups have long contended that too few debtors choose the rehabilitation option. Many debtors who obtain immediate discharge, they argue, could pay their creditors more if they proposed a rehabilitation plan instead. Creditor groups have argued vehemently since the rg6os that debtors who are capable of repaying some of their debt over time should be forced into Chapter I $3 .{ }^{89}$

In As We Forgive Our Debtors and elsewhere, Warren sharply criticizes the credit industry's proposals for steering more debtors into Chapter I3. Warren and her co-authors point out that a substantial percentage of debtors who do embark on repayment plans are unable to complete them. ${ }^{90}$ Although a prominent study sponsored in part by

84 Sullivan, WARREN \& WeSTBROOK, supra note 82, at I7. For a detailed description of the study and its methodology, see $i d$. at $17-19$. Unlike Douglas, Warren and her co-authors relied for their study on filing data rather than on interviews with debtors.

85 See id. at $17-18$.

86 See id. at 65 .

87 See id. at $84-105$.

38 See id. at 208. Congress added the second option, which was traditionally known as a "wage earner plan," in I938. For a description of this development, see H.R. REP. NO. 75-1409, at 52-55 (1937). Although this approach delays a debtor's discharge, lawmakers believed it would reduce the stigma of bankruptcy. If debtors committed to continue paying for several more years, lawmakers reasoned, they and their creditors would be less likely to view bankruptcy as abandoning their obligations. To reinforce this perception, debtors who sought an immediate discharge were referred to as "bankrupts" until 1978 , whereas those who proposed a rehabilitation plan were called "debtors."

89 For a brief, condemnatory overview of the creditor groups' position, see Vern Countryman, Bankmptcy and the Individual Debtor - And a Modest Proposal to Return to the Seventeenth Century, 32 CATH. U. L. REV. 809, 82 I-26 (1983).

90 See SUllivan, WARREN \& WeSTBROOK, supra note 82, at 220-23. 
the credit industry concluded that Chapter 7 debtors could pay off more than four billion dollars of debt if they used Chapter I3, Warren and her co-authors dismiss the findings as unreliable. ${ }^{91}$

Warren and her co-authors are similarly skeptical of claims that debtors could be encouraged to choose the repayment alternative rather than immediate discharge if lawmakers made adjustments such as reducing debtors' exemptions. ${ }^{92}$ In both her co-authored and solo work, Warren rejects the suggestion that debtors will respond in a simple, predictable way to changes in the bankruptcy laws. "This premise [that reducing exemptions will cause more debtors to choose Chapter I3]," she argues, "calls to mind thousands of almost-bankrupt rational maximizers sitting anxiously on some hypothetical cost/benefit curve, waiting for the numbers to come down from Congress."93 The reality is much more complex and, in fact, existing data cast serious doubt on the contention that exemptions can be used to shape debtor behavior. ${ }^{94}$

As this overview suggests, the policy proposals of As We Forgive Our Debtors are principally negative in form: lawmakers should preserve the current framework and protect debtors rather than accede to creditors' cries for reform..$^{95}$

91 In an earlier article, Warren and her co-authors subjected the study (known as the "Purdue Study," based on the university affiliation of its authors) to withering scrutiny. See Teresa A. Sullivan, Elizabeth Warren \& Jay Lawrence Westbrook, Limiting Access to Bankruptcy Discharge: An Analysis of the Creditors' Data, I983 WIS. L. REV. Iogr. They concluded:

The Study lacks crucial expertise, is designed incorrectly, asks a series of inartful questions, gathers its data improperly, misanalyses the statistical data and draws erroneous and biased inferences from the data analysis. Moreover, error after error increases the count of the debtors who "could pay" and the amount of the debt that could be recovered....

Id. at 1455 .

92 The theory was that if Congress diminished debtors' exemptions, debtors would be unable to protect their property and still receive an immediate discharge. If the exemptions were too small to protect important property, and debtors wanted to keep the property, they would need to

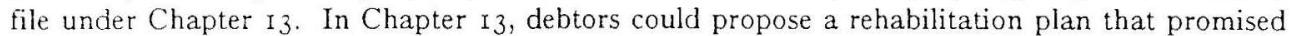
ongoing payments to creditors while permitting the debtors to keep their property. In Chapter 7 , on the other hand, nonexempt property would be sold and the proceeds distributed to creditors. For a general discussion of exemptions, see p. 1082

93 Elizabeth Warren, Reducing Bankruptcy Protection for Consumers: A Response, 72 GEO. L.J. I 333 , I343 (I 984 ).

94 See id. at $1344-45$ (citing evidence that a disproportionate percentage of debtors in Texas choose Chapter 13, despite high exemptions, and that lower exemptions do not decrease bankruptcy filings); see also SULLIVAN, WARREN \& WESTBROOK, supra note 82, at I9-20 (suggesting that the authors' data cast doubt on the assumption in the 1984 amendments to the Bankruptcy Code that altering the statute would influence debtors' filing decisions).

95 See Sullivan, WARREN \& WestbroOK, supra note 82, at 339-4I (summarizing conclusions). Warren and her co-authors have revisited their findings in a new study. Their preliminary analysis confirms the general conclusions of $A s$ We Forgive Our Debtors. See Teresa A. Sullivan, Elizabeth Warren \& Jay Lawrence Westbrook, Consumer Debtors Ten Years Later: A Financial Comparison of Consumer Bankrupts I98I-I99I, 68 AM. BANkR. L.J. I 2 I, I25 (1994). 
Warren's work on personal bankruptcy marks her as an obvious intellectual heir of William Douglas, yet it also reveals subtle differences. As noted above, the most obvious kinship between Douglas and Warren lies in their shared commitment to empirics. Both insist that reform must be grounded in careful attention to empirical data. When Warren emphasizes (in another context) that her policy analysis "takes its cue from the tradition of legal realism, asserting that real-world constraints necessarily - and properly - bind bankruptcy policy, and that only in a specified factual context does a policy discussion become meaningful,"9o it is hard not to think of William Douglas. Yet Warren is far less sympathetic than Douglas to using the law instrumentally, especially when the aim is to shape debtors' behavior.

The question whether debtors should receive an immediate discharge nicely illustrates these similarities and differences between Warren's and Douglas's work on personal bankruptcy. Douglas criticized the immediate discharge, and contended that courts should be permitted to postpone or condition the cancellation of a debtor's obligations. Both Douglas's urge to experiment and his interest in molding debtor behavior stand in contrast to Warren's reluctance to tinker with the bankruptcy discharge.

Like Douglas in the 1930s, Warren turned her attention to debates about corporate reorganization after writing $A s$ We Forgive Our Debtors, although she has continued to devote considerable energy to personal bankruptcy issues. Douglas was thrown headlong into corporate reorganization by Congress's call for the SEC to investigate reorganization practice. For Warren, as for other recent bankruptcy scholars, the pivotal event was the enactment of the 1978 Bankruptcy Code. The Bankruptcy Act had imposed rigid requirements on the reorganization of large, publicly held corporations. ${ }^{97}$ In addition to the mandatory trustee requirement and the exclusion of a debtor's bankers and attorneys, the chapter for large debtors also required strict compliance with the absolute priority rule..$^{98}$ As noted earlier, both can be traced to William Douglas: Chapter $\mathrm{X}$ explicitly required an independent trustee, and Douglas authored the two Supreme Court decisions holding that the "fair and equitable" standard, which was a requirement for reorganization under both Chapter $\mathrm{X}$ and prior law, incorporated the absolute priority rule. ${ }^{99}$ These requirements made bankruptcy an extraordinarily undesirable prospect for the managers and sharehold-

96 Elizabeth Warren, Bankruptcy Policymaking in an Imperfect World, 92 MICH. L. REV. 336 , 378 (I 993) (focusing on corporate bankruptcy).

97 As described above, the drafter and principal advocate for these provisions was William Douglas himself. See supra pp. I088-gI.

98 See supra p. I092.

99 See id. 
ers of a troubled firm, because their interests would be wiped out in bankruptcy. 100

The 1978 Code brought dramatic change to corporate reorganization. Chapter I I, the Code's new corporate reorganization provisions, assumed that the firm's managers (not an independent trustee) would continue to run the firm in bankruptcy and gave the managers the exclusive right to propose a reorganization plan for at least the first four months of the reorganization. ${ }^{101}$ Chapter I I also significantly retrenched from the absolute priority rule: the rule would not apply to any class of creditors on shareholders who voted in favor of the proposed plan. ${ }^{102}$ These changes made bankruptcy much more attractive for large, troubled corporations and, by the late I 980 and early Igoos, an unprecedented number of prominent firms had filed for bankruptcy in response to failed leveraged buyouts and other problems. ${ }^{103}$ In I 983, Continental Airlines filed for Chapter I I and used bankruptcy to renegotiate its collective bargaining agreement with employees. ${ }^{104}$ Federated Department Stores filed for bankruptcy after a disastrous leveraged buyout, and both Johns Manville and A.H. Robins invoked Chapter I I in the face of mushrooming tort liability. ${ }^{105}$

The new popularity of bankruptcy in the executive suite proved controversial. Although some observers cheered these developments, others leveled a variety of complaints. Critics asserted both that managers were strategically using bankruptcy as a tool for addressing business concerns even in the absence of true financial distress ${ }^{106}$ and that Chapter I I proceedings could be extraordinarily costly and timeconsuming for those with firms that did belong in bankruptcy. The only winners in many cases seemed to be bankruptcy lawyers and other professionals who charged by the hour. ${ }^{107}$

100 To avoid these strictures, an increasing number of large firms attempted to file for bankruptcy under Chapter XI, the provisions designed for smaller debtors. The SEC tried, but ultimately failed, to prevent this practice. For a discussion and political explanation of the demise of the SEC in bankruptcy, see Skeel, supra note $6 \mathrm{I}$.

101 See II U.S.C. \$ Iro7 (I994) (vesting authority in "debtor in possession"); I I U.S.C. \$ I I2I (I994) (providing a I20-day exclusivity period).

102 See II U.S.C. § I I 2 (b) ( I 994) (applying the absolute priority rule only if the class dissents).

103 See KEvin H. Dellaney, STRATEgiC BANkruptCy: How CORPORATIONS AND

THEIR CREDITORS USE CHAPTER I I TO THEIR ADVANTAGE 2-3 (r 992 ).

104 See id. at $\mathrm{I}-2$.

105 See id. at 3.

106 See, e.g., Richard B. SObOl, Bending The LAw: The Story of the Dalkon SHIELD BANKRUPTCY 337, 339-40 (I99I) (describing and criticizing the treatment of Dalkon Shield victims in the A.H. Robins bankruptcy).

107 For a scathing account of this process - and the burden of lawyers' fees and other costs by the manager of a firm that filed for bankruptcy, see SOL STEIN, A FEAST FOR LAWYERS (I989). 
Whatever the merits of these complaints, they are closely linked to the changes effected by the 1978 Code. Leaving managers in charge and relaxing the absolute priority rule have given the managers of large corporate debtors much more flexibility than they had in the past. This flexibility and the managers' exclusive right to propose a plan are the most obvious explanations for the prolonged duration of Chapter II cases. ${ }^{108}$

In a I 992 article, Michael Bradley and Michael Rosenzweig sharply criticize managers' role in corporate reorganization and call for a complete revision of the Chapter II regime. ${ }^{109}$ Based on an extensive analysis of the securities prices of firms that wound up in bankruptcy, Bradley and Rosenzweig suggest that firms fare far worse under Chapter II than they would have under the prior Bankruptcy Act. ${ }^{110}$ They argue that Congress should replace Chapter II with a stock cancellation regime that simply eliminates shareholders' interest in the event the firm defaults on its obligations. In place of the flexible approach of Chapter II, their proposal would enforce a severe version of absolute priority.111

If the views of William Douglas and the early bankruptcy progressives could simply be plugged into these debates about corporate reorganization, then we might expect current progressives to have agreed with at least some aspects of the Bradley and Rosenzweig analysis. The Bradley and Rosenzweig article sharply criticizes managers and strongly favors strict absolute priority and was viewed by the corporate bankruptcy bar as a direct assault on existing practice. ${ }^{112}$ William Douglas, of course, took precisely the same stance on each of these issues. Yet bankruptcy progressives uniformly have condemned the Bradley and Rosenzweig analysis, as evidenced most prominently in an attack by Elizabeth Warren, who sharply criticized the empirical analysis of the controversial article and has defended Chapter ir. ${ }^{113}$

\footnotetext{
108 See Lynn M. LoPucki, The Trouble with Chapter II, I993 WIS. L. REV. 729, 747-49.

109 See Michael Bradley \& Michael Rosenzweig, The Untenable Case for Chapter II, IOI YALE L.J. IO43 (1992).

110 See id. at 1049, $1067-72$.

111 See id. at 1050, 1078-88. In the wake of the Bradley and Rosenzweig article, law and economics scholars proposed a variety of other alternatives to Chapter II. See, e.g., Barry E. Adler, Financial and Political Theories of American Corporate Bankruptcy, 45 STAN. L. REV. 3II, 3I2, 323-33 (1993) (arguing for a stock cancellation proposal similar to Bradley's and Rosenzweig's proposal); Robert K. Rasmussen, Debtor's Choice: A Menu Approach to Corporate Bankruptcy, 7 I TEX. L. REV. 5 I, IOO-2 I (I992) (proposing a "menu" approach allowing debtors to select from a variety of bankruptcy options).

112 See Wade Lambert \& Milo Geyelin, Bankruptcy Lawyers Dispute Call for Scrapping Chapter 1 I Process, Wall ST. J., Mar. I9, I992, at B5.

113 See Elizabeth Warren, The Untenabie Case for Repeal of Chapter II, IO2 YALE L.J. 437, 439-79 (I992). Lynn LoPucki was equally dismissive. See Lynn M. LoPucki, Strange Visions in a
} 
Although earlier progressives would have agreed with much of Warren's critique - namely, her concerns about the data and the limited real-world grounding of the proposed reform - it is useful to elaborate on their differences, which reflect the changes in progressive thinking. In her response to Bradley and Rosenzweig, and elsewhere, Warren worries much less than Douglas did that managers will use bankruptcy to the detriment of other parties. She and other progressives rew cases such as Continental, in which managers invoke Chapter I t to achieve particular objectives, as bankruptcy successes, not failures.14 Similarly, Warren has a great deal of sympathy for the Gexibility of Chapter I I and its relaxed treatment of the absolute priority rule. Like Douglas, Warren cares deeply about distributional issues - who wins and who loses in bankruptcy. One of her most frequent criticisms of law-and-economics-based bankruptcy scholarship is that it ignores distributional effects. ${ }^{115}$ Yet she has a very different vision for achieving distributional fairness. Whereas Douglas insisted on displacing managers and strictly adhering to the absolute priority rule, Warren suggests that leaving managers in place and providing a more flexible bankruptcy process are essential to achieving bankruptcy's distributional goals. In her most detailed analysis of the functions of business bankruptcy, for instance, Warren emphasizes the virtues of giving managers a stake in the bankruptcy decision and encouraging reorganization to preserve the going concern value of a troubled firm. ${ }^{116}$

Warren's enthusiasm for the current Chapter I I regime also reflects a remarkably different stance toward the corporate reorganization bar than the one taken by Douglas in the I930s. As we saw earlier, Douglas vigorously attacked the bar of his day - bankruptcy lawyers were the target of much of his criticism of existing practice. ${ }^{117}$ By con-

Strange World: A Reply to Professors Bradley and Rosensweig, 9I MICH. L. REV. 79, 8 I-IIO (1992).

114 See Elizabeth Warren, Banknuptcy Policy, 54 U. CHI. L. REV. 775, 787 (1987) (listing Continental as one of "a host of ... bankruptcy success stories"). Although Warren acknowledges critics' concerns about Chapter II, she argues that outcomes would be far worse in the absence of the reorganization provisions. See Elizabeth Warren, Bankruptcy Is a Better Alternative, NAT'L L.J., Apr. 20, 1992, at I5 [hereinafter, Warren, Better Alternative].

115 In an exchange with law and economics scholar Douglas Baird, Warren repeatedly criticized Baird's effort to bracket distributional considerations: "Baird cannot assert that he is offering no distributional scheme .... Any scheme distributes, whether Baird chooses to discuss it or not." Warren, Bankruptcy Policy, supra note II4, at 808.

116 Warren argues that the bankruptcy system as a whole is designed to address four separate, though interrelated, goals: maximizing the value of the troubled firm, distributing value (by taking distributional concerns into account), internalizing the costs of failure, and encouraging debtors and their managers to initiate bankruptcy, rather than relying on governmental officials to do so. See Warren, supra note 96 , at 344-73. In Warren's view, the more manager-friendly confines of Chapter I advance both the first and fourth of these goals. See id. at 372 .

117 See supra pp. 1087, 1090. 
trast, the views of Warren and other current progressives sound surprisingly similar to those of the lawyers whom Douglas was busy assailing. In a 1927 article on priorities in bankruptcy, for instance, bankruptcy lawyer Robert Swaine defended relaxed priority rules as essential to promoting reorganization. ${ }^{118}$ More recent bankruptcy progressives share Swaine's assumption that reorganization must be encouraged, despite the attack on this position by their predecessor Douglas.

Not surprisingly, these views have endeared bankruptcy progres. sives to the current corporate reorganization bar. ${ }^{119}$ It is difficult to imagine the members of the National Bankruptcy Conference inviting William Douglas to join them in the I930s, as they did Elizabeth Warren in the early iggos. By all accounts, Warren has become an enormously influential member of the Conference, which has long been the bankruptcy bar's most prominent reform and lobbying organization. ${ }^{20}$

In I995, Warren was appointed chief advisor to the newly formed National Bankruptcy Review Commission.121 For the next two years, she led the Commission in the most thorough assessment of U.S. bankruptcy law in twenty years. The Commission's proposals reflect many of the progressive views that I discuss above. In the context of personal bankruptcy, the Commission strongly endorsed debtors' access to an immediate discharge, and rejected calls by creditors for means testing provisions that would force debtors to use Chapter $\mathrm{I}_{3}$ if they were able to repay some of their debts. ${ }^{122}$ In an effort to preempt the

118 See Swaine, supra note 75 , at 907 .

119 Other prominent progressives, such as Lynn LoPucki and Karen Gross, have also established (or maintained) close ties to the bankruptcy bar.

120 Warren has served as a member of the executive committee and as a chair of the new members committee. See E-Mail Correspondence from Professor Douglas Baird, University of Chicago Law School, to David Skeel (Feb. 9, 2000) (on file with the author); see also Telephone Interview with Gerald Smith, Lewis \& Roca, Phoenix, Ariz. (Feb. 8, 2000) (noting Warren's influence).

121 Depending on how one counts (and what one includes), this Commission, which issued its report in October 1997 , was the fourth major governmental study of bankruptcy in this century. The four studies are: I) the Donovan and Thacher reports of the early I930s, which investigated abuses in bankruptcy administration, see supra note $48 ; 2$ ) the SEC "protective committee" study headed by William Douglas, see supra pp. I088-89; 3) a report by the National Bankruptcy Commission of 1973 , which proposed the sweeping overhaul of U.S. bankruptcy law that eventually led to the enactment of the 1978 Code, see COMMISSION ON THE BANKR. LAWS OF THE UNITED STATES, REPORT, H.R. DOC. NO. 93-137, (1973) [hereinafter I973 COMMISSION REPORT]; and 4) a report by the National Bankruptcy Review Commission of I 997 , see NAT'L BANkR. REVIEW COMM'N, BANKRUPTCY: THE NEXT TwENTY YEARS (I997), available at National Bankruptcy Review Commission (visited Jan. 24, 2000) <http://www.nbrc.gov/reportcont.html> [hereinafter I997 COMMISSION REPORT].

122 See I 997 COMMISSION REPORT, supra note I2 I, ch. I, at 89-9I (criticizing "means testing" proposals that would require more debtors to use Chapter 13 and concluding that the Commission's "proposals contemplate no change in the basic structure of consumer bankruptcy"). Warren explains the Commission's views and defends the immediate discharge against criticism by the consumer credit industry in several articles published since the 1997 Commission Report was re- 
I997 Commission proposals, the consumer credit industry introduced legislation that had considerable support in Congress last fall and is currently pending. Warren has served as an informal advisor to Hillary Clinton, ${ }^{123}$ and has actively campaigned against this legislation.

In business bankruptcy, the Commission worked closely with the bankruptcy bar and proposed to preserve and in several respects to expand the current framework. The Commission's deliberations on "prepackaged bankruptcies" are illustrative. In a prepackaged bankruptcy, a troubled firm's managers solicit support for a reorganization proposal before they file for bankruptcy. They then submit the firm's proposed reorganization plan along with the initial bankruptcy petition. William Douglas and the bankruptcy progressives railed against pre-bankruptcy solicitations in the I930s, and such solicitations were forbidden from I938 until Congress again authorized them in $1978.1^{124}$ The Commission, by contrast, supported prepackaged bankruptcy: one staff memo even proposed to expand it significantly by exempting prebankruptcy solicitations from the federal securities laws. ${ }^{125}$ The Commission's final recommendation was slightly more limited but nonetheless evinces an unmistakable enthusiasm for prepackaged bankruptcy and for the flexible Chapter I r reorganization process as a whole. ${ }^{126}$

leased. See Elizabeth Warren, The Bankruptcy Crisis, 73 IND. L.J. I080 (I998) (analyzing and answering studies on bankruptcy sponsored by the consumer credit industry); Elizabeth Warren, A Principled Approach to Consumer Bankruptcy, 7 I AM. BANKR. L.J. 483 (I997) (discussing the process that influenced the Commission's recommendations about the consumer bankruptcy system) [hereinafter Warren, $A$ Principled Approach].

123 See Katharine Q. Seelye, First Lady in a Messy Fight On the Eve of Her Campaign, N.Y. TIMES, June 27,1999 , at AI ("In the spring of I998, Mrs. Clinton sought a private tutorial in bankruptcy law from a Harvard Law professor, Elizabeth Warren, who has strongly opposed the legislation.").

124 Douglas and the early progressives believed that the practice of pre-bankruptcy solicitation magnified the influence of the Wall Street bankers and lawyers, because it allowed them to take advantage of the limited information and influence of scattered investors. As noted earlier, the Chandler Act addressed this concern by prohibiting the parties from soliciting the approval of banks and lawyers until after the court had given its blessing to the reorganization plan in question. See Pub. L. No. $95-598,92$ Stat. 2682 (repealed 1978 ). The 1978 Code expressly authorizes pre-bankruptcy solicitations. See II U.S.C. \$ II26 (I994).

125 See Memorandum from Jay M. Goffman, Skadden, Arps, Slate, Meagher \& Flom to Elizabeth Warren, Proposed Amendments to Bankruptcy Code and Securities Lanes Relating to Prepackaged Bankruptcy Cases 5-6 (June I2, 1997) (on file with the author).

126 See I997 COMMISSION REPORT, supra note I2 I, ch. 2, at 589-95 (applying the rules of the Bankruptcy Code and waiving securities law disclosure requirements for solicitations made within 120 days prior to bankruptcy). The Commission's proposal to exempt prepackaged bankruptcy from the securities laws did not meet uniform approval. For example, it drew a concerned letter from Richard Walker, General Counsel of the SEC, who questioned whether the need to reduce costs and streamline bankruptcy "is a sufficient basis for the elimination of important securities law protections for public investors provided by Securities Act registration." Letter from Richard H. Walker, General Counsel, SEC, to National Bankruptcy Review Commission (Oct. I, I997) (on file with the author). 
Clearly something has changed in the years since William Douglas first campaigned for bankruptcy reform. The reader probably suspects that there are good reasons for the shift in progressives' views, and there are. Many of the problems that preoccupied Douglas and his peers were addressed by the New Deal financial and market reforms, for instance; other concerns took their place. To appreciate how progressive thinking has evolved, we must turn to the scholar whose work connects Douglas and current progressives: Vern Countryman.

\section{VERN COUNTRYMAN: THE LINK BETWEEN THEN AND NOW}

Many of us remember from childhood a game called "Whispering Down the Lane."127 In Whispering Down the Lane, one child whispers a statement or anecdote to the second child in a chain, and the second child to a third. By the time the message gets back to the first child, it often bears little resemblance to that child's original statement. Something like this distortion seems to have taken place, at least superficially, in progressive bankruptcy scholarship. As we move from Douglas to Countryman to Warren, the perspective on bankruptcy changes dramatically. Yet it is also clear that the general goals - the commitments - of progressive scholars have remained stable.

In this Part, I explain why progressives' vision of bankruptcy has changed, even as their overall goals have endured. The inquiry leads us straight to the central link in the chain: Vern Countryman. In ways both simple and complex, arising both from his own disposition and from changes in debtors, investors, and the credit markets, Countryman marks the transition between the past and present of progressive bankruptcy theory.

This Part begins by considering Countryman's personal and intellectual relationship with William Douglas. Despite their close ties, Countryman's perspective on bankruptcy differed from Douglas's in three crucial respects. First, Countryman focused far more on personal bankruptcy, whereas Douglas was best known for his work on large-scale corporate reorganization. Second, unlike Douglas, who repeatedly attacked the bar of his day, Countryman developed a close working relationship with the bankruptcy bar. Finally, Countryman was far more skeptical than Douglas of instrumental analysis, as evidenced by Countryman's hostile response to the emerging law and economics movement. After developing each of these distinctions in the first section, this Part considers how these tendencies have influenced the work of Elizabeth Warren and other current bankruptcy progressives. By tracing the course of progressive bankruptcy scholarship from Douglas to Countryman and from Countryman to current

127 Others may remember the game as "Rumors," "Operator," or "Telephone." 
scholars, this Part shows how and why the focus of progressive scholars has shifted since its origins in the work of William Douglas.

\section{A. Almost in His Mentor's Footsteps}

The link between Vern Countryman and the leading New Deal bankruptcy progressive, William Douglas, could not be more explicit. Like Douglas, Countryman grew up in the West and attended college in the state of Washington. Upon graduating from law school in 1942, Countryman applied for a clerkship with Justice Douglas, who had been appointed to the Supreme Court just three years earlier. The letter of recommendation written by the dean of Countryman's law school suggests why Douglas found his application so attractive. Countryman's credentials were impressive. He graduated third in his class and served as President of the Washington Law Review. ${ }^{28}$ At least as impressive, however, was the fact that Countryman had supported himself throughout college and law school. "During the summer vacations," the dean wrote, "he has worked as a manual laborer in the saw mill and pulp and paper mills at Longview. During the school years, he has worked part-time."129 This fact surely reminded Douglas of his own experiences working himself through college, which he remembered with pride throughout his life. ${ }^{130}$ Douglas offered Countryman the clerkship, and he soon became Countryman's mentor.

Countryman served as Douglas's clerk during the I942 Term, shortly after Douglas had written several enormously important bankruptcy decisions. ${ }^{131}$ Countryman's clerkship was a smashing success, and in subsequent years, Douglas would repeatedly refer to Countryman as having been one of his best clerks ever.

After his clerkship and a two-year stint in the Army during World War II, Countryman entered academia, just as Douglas had done. ${ }^{132}$

128 See Letter from Judson F. Falknor, Dean, University of Washington School of Law, to Justice William O. Douglas (June I8, I 942) (on file with the Library of Congress, Douglas Papers, Container No. I I 8). Attached to the letter is a copy of Countryman's law school transcript.

129 Id.

130 Douglas's biographer reports that Douglas "had been hired as an all-purpose handyman at Falkenberg's Jewelry Store" prior to his freshman year at Whitman College in Walla Walla, Washington. "He had also signed on as an early-morning janitor in a candy store and as a dinnerhour waiter in a hash house." SIMON, supra note 19, at 48. For Douglas's own account of his crowded college schedule, see DOUGLAS, GO EAST, supra note 64 , at 97-98.

131 Two of the most important were Douglas's decisions defining the absolute priority rule. See Consolidated Rock Prods. Co. v. Du Bois, 3 I2 U.S. 5 Io (I94I); Case v. Los Angeles Lumber Prods. Co., 308 U.S. I06 (1939); supra p. 1092.

132 After the clerkship and his time in the Army, and before leaving for Yale Law School in I947, Countryman taught for a year at the University of Washington School of Law. See AsSOCiation of AMERICAN LAW SCHOOLS, ThE AALS DiRECTORY OF LAW TEACHERS: I998-99, at 360 (r998) (containing biographical data for Countryman). 
With a glowing recommendation from Douglas, ${ }^{133}$ he was awarded a fellowship at Yale Law School for I 947 and appointed to the Yale faculty the following year. Not surprisingly, given his relationship with Douglas, Countryman chose to specialize in bankruptcy law.

During his years at Yale, Countryman became involved in the loyalty cases that would mire his career in controversy. Like many New Deal liberals, Countryman was appalled by the treatment of individuals who had been accused of ties to the Cornmunist Party. By the early I950s, it was clear that defending those accused of un-American activities was a dangerous career move for a lawyer or law professor. ${ }^{134}$ Countryman did not flinch. He wrote a critical book on the investigation of un-American activities in the state of Washington and a series of articles on the plight of lawyers who defended individuals accused of Communist Party activities. ${ }^{135}$ (Douglas took a similar stance from his perch on the Supreme Court, authoring a prominent dissenting opinion insisting that the defendants' First Amendment rights were being violated. ${ }^{136}$ ) Countryman also became actively involved in several cases; most galling to the Yale administration was his defense of Yale Medical School professor John Peters, who was accused of un-American activities but later vindicated..$^{137}$

In 1954, after the law school faculty unanimously voted to grant Countryman tenure, Yale's president, Alfred Griswold, and the new law school dean, Harry Shulman, refused to move forward with his application. Justice Douglas was a powerful presence in Yale circles during this era, and when he learned of Countryman's troubles, he sent angry letters to both the president and the dean. "Yale Law has had a great liberal tradition," he wrote to President Griswold:

There are many who feel that that tradition will suffer grievously if Countryman's ability and character are not recognized.... He has a keenedged [mind], one of the best I have known. He has, I understand, been

133 Douglas wrote to Wesley Sturges, a close friend and by this time the dean of Yale Law School:

[Countryman] is a first-rate man in every respect. He did excellent work for me. And I would rate him as high as any law clerk I have known at the Court. ... He has a very superior mind, great capacity for work, imagination, creative ability, and resourcefulness. He is an unusually gifted person.

Letter from Justice William O. Douglas to Wesley A. Sturges, Dean, Yale Law School (May 3, I946) (on file with the Library of Congress, Douglas Papers, Container No. I I I).

134 For a fascinating account of the loyalty cases from the perspective of Abe Fortas and the Washington law firm now called Arnold \& Porter, which was one of the few law firms willing to represent loyalty case defendants, see LAURA KALMAN, ABE FORTAS: A BIOGRAPHY I25-5 I (1990).

135 See sources cited cited above in note g. For a description of Countryman's role, and of the Yale tenure fight described in the text below, see KALMAN, cited above in note I 7 , at I 96-200.

136 See Dennis v. United States, 34I U.S. 494, 58 I-92 (195 I) (Douglas, J., dissenting).

137 See Kalman, supra note 17 , at 197. 
active in certain loyalty cases. But that too is in the tradition of the law, at least from the time of Erskine who defended Tom Paine in court. ${ }^{138}$

To Dean Shulman, Douglas was even more sirident: "If Countryman is denied promotion, think of the reaction [of] the law clerks of today. Those who want to teach will look elsewhere. As some young Yale Law alumni told me in St. Louis last Saturday, "Countryman is the best teacher Yale has today." "139

In the end, the Yale administration would not be persuaded. Griswold and Shulman insisted that they had focused on Countryman's scholarship, not his loyalty activities, and they attempted to defuse the controversy by offering to reappoint Countryman for several more years and to revisit the tenure issue in the future. Instead of accepting, Countryman resigned. ${ }^{140}$ He worked for several years in a Washington, D.C. law firm, then returned to academia to accept the deanship at the University of New Mexico School of Law. In 1964, Countryman was appointed to the faculty at Harvard Law School, where he would spend the final two decades of his career. Given Harvard's longtime reputation as somewhat stodgy and less cutting-edge than Yale, ${ }^{141}$ the appointment surprised and delighted both Countryman and his mentor. "I have accepted a permanent appointment here," Countryman wrote to Douglas, "largely because I couldn't resist the opportunity to sound a dissenting voice from this forum."142 Douglas responded: "[The appointment is] the nicest thing I have heard about Harvard Law School in a long time. I cannot believe they are looking for enlightenment but the mere fact that they did tolerate harassment makes them deserving of some credit." 143

Throughout his career, Countryman did as much to promote Douglas's reputation as his mentor had done for him. Countryman was long known as Douglas's principal defender in the academic world. In 1959, he published a book of Douglas's Supreme Court decisions, and he wrote numerous laudatory articles on the Justice's

138 Letter from Justice William O. Douglas to Dr. Alfred Whitney Griswold, President, Yale University (Jan. 26, I955) (on file with the Library of Congress, Douglas Papers, Container No. III 8).

139 Letter from Justice William O. Douglas to Harry Shulman, Dean, Yale Law School (Jan. 27, I955) (on file with the Library of Congress, Douglas Papers, Container No. I I 18).

140 See KaLman, supra note 17 , at I $98-99$.

141 Harvard's reputation dated back to the rise of legal realism and the attack on Langdellian legal science in Douglas's era, and included often bitter attacks by Yale professors on Harvard Law School, and vice versa. See KALMAN, supra note 17, at 25-29.

142 Letter from Vern Countryman to Justice William O. Douglas (undated) (on file with the Library of Congress, Douglas Papers, Container No. in is).

143 Letter from Justice William O. Douglas to Vern Countryman (Jan. I4, I 964) (on file with the Library of Congress, Douglas Papers, Container No. I I 8 ). 
handiwork. ${ }^{144}$ Countryman's close intellectual and personal bond with Douglas was a pervasive feature of his academic career, and it extended, of course, to Countryman's work on bankruptcy. Like Douglas before him, Countryman was the leading progressive bankruptcy scholar of his era, and he co-authored an influential legal realist casebook on bankruptcy law. ${ }^{145}$ Despite the continuities, however, Countryman's perspective on bankruptcy differed from that of Douglas in several subtle but crucial respects. These divergences refiected both changes in the world since Douglas's bankruptcy work in the I93os, and differences in Countryman himself.

I. Countryman's Concentration on Personal Bankruptcy. The most obvious difference between Countryman's writings and those of Douglas is one of emphasis: although Douglas wrote about both personal and corporate bankruptcy, large scale corporate bankruptcy came to dominate Douglas's attention after his appointment to the SEC, and he is best known for his work on corporate reorganization. Countryman, by contrast, showed much more interest in personal bankruptcy than in business failure. Like Douglas, he wrote on both, but far more of his work focused on personal bankruptcy. At first glance, emphasizing personal rather than corporate bankruptcy may not seem significant. But the two differ in important respects, due in part to the contrast between individuals and artificial entities such as corporations. ${ }^{146}$ These distinctions figured prominently in the emergence of current progressive bankruptcy theory.

Although it is impossible to know for sure why Countryman gravitated toward personal bankruptcy rather than business issues, there is a readily inferable connection to his concern for civil liberties and individual freedoms. When asked about Countryman's focus on indi-

144 See Douglas of the Supreme Court: A Selection of His Opinions (Vern Countryman ed, I 959). Countryman's articles on Douglas include Vern Countryman, Scholarship and Common Sense, 93 HARV. L. REV. 1407 (1980) [hereinafter, Countryman, Common Sense]; Vern Countryman, Search and Seizure in a Shambles? Recasting Fourth Amendment Law in the Mold of Justice Douglas, 64 IOWA L. REV. 435 (1979); Vern Countryman, Justice Douglas and Freedom of Expression, 1978 U. ILL. L.F. 30 I (I978); Vern Countryman, The Contribution of the Douglas Dissents, IO GA. L. REV. 33 (1976); Vern Countryman, Business Regulation, 74 Colum. L. REV. 366 (I974), one of a group of articles in tribute to Justice Douglas; Vern Countryman, $J u s-$ tice Douglas: Expositor of the Bankruptcy Law, I6 UCLA L. REV. 773 (1969); and Vern Countryman, The Constitution and Job Discrimination, 39 WASH. L. REV. 74 (1964).

145 See VERn COUNTRYMan \& JAMES WILliam MOORE, DEBTORS' ANd CREdiTORS' RIGHTS: CASES AND MATERIALS (I95I); see also KALMAN, supra note 17 , at I89 (describing Countryman's casebook as squarely within the legal realist tradition). Countryman also coauthored a casebook on lawyers and legal ethics. VERn COUNTRYMAN \& TED FInMan, The LAWYER IN MODERN SOCIETY (i g66).

146 The strongest justification for discharging an individual's obligations - to give her a "fresh start" that relieves her of her burden of debt and motivates her to try starting anew - applies much less powerfully to a corporate debtor because corporations are artificial entities that do not need to be preserved if they are financially unviable. 
vidual bankruptcies, one longtime friend and prominent lawyer immediately noted Countryman's identification with the "little guy."147 Another recalled that when Countryman first became involved in the consumer law committee of the American Bar Association, he was appalled that consumer creditors dominated the activities while debtors seemed to have no voice. ${ }^{148}$ It is not surprising that the bankruptcy scholar who defended the liberties of men and women accused of subversion in the I950s also stood up for troubled debtors in the decades that followed.

Justice Douglas was also famous for his emphasis on individual liberties, of course. In a tribute to Douglas after the Justice's death, Countryman praised his mentor for taking "a more hospitable view of individual freedom under the Constitution than any other Justice before and since,"149 and for "tak[ing] government off the backs of people."150 But these issues were not quite so pressing for bankruptcy scholars in the I930s, when Douglas was writing, as they would become in the Ig6os, when Countryman had assumed the mantle of the leading progressive bankruptcy scholar. ${ }^{151}$ The battles over individual liberties in the I95os may have had a ripple effect on the field of bankruptcy, focusing attention on the travails of financially troubled debtors. Of much more obvious and immediate significance, however, were changes in the credit markets.

Prior to World War II, ordinary consumers had only limited access to credit. Many individuals conducted all of their transactions in cash, except for credit arrangements with grocers and other small suppliers. After World War II, consumer credit exploded. In addition to the sustained growth of home mortgage lending, installment credit increased, and the advent of credit cards made consumer credit available at previously unheard-of levels. The overall effect was unmistakable. As Countryman frequently noted at congressional hearings and elsewhere, total consumer credit exclusive of mortgages expanded from $\$ 30$ billion in 1945 to more than $\$ 569$ billion in $1974 .{ }^{152}$ Along with the vast

\footnotetext{
147 Telephone Interview with Gerald Smith, Lewis \& Roca, Phoenix, Ariz. (Aug. 9, I 999).

148 See Telephone Interview with Professor Lawrence King, New York University School of Law (July 20, I 999).

149 Countryman, Common Sense, supra note 144, at 1407

150 Id. (quoting Schneider v. Smith, 390 U.S. I7, 25 (rg68) (Douglas, J., dissenting)) (internal quotation marks omitted).

151 Countryman may have been even more committed to civil liberties than was Douglas. In an interview many years after his clerkship with Douglas, Countryman recounted their passionate arguments on the first Japanese internment case. Countryman insisted that internment violated Japanese-American citizens' First Amendment rights, but Douglas voted with the Supreme Court majority to uphold the wartime measure. See SIMON, supra note 19, at 242-43 (describing Countryman's and Douglas's arguments about Hirabayashi v. United States, 320 U.S. 8I (I943)).

152 See, e.g., Countryman, supra note 68, at I (citing FED. Reserve Bull. A52, A54 (Dec. I970)); id. at $\mathrm{A}_{44}, \mathrm{~A}_{47}$ (July 1974)). At the same time, personal bankruptcy filings also expanded
} 
expansion of consumer credit and consumer sales came increasing complaints of creditor misbehavior. The most dramatic response outside of bankruptcy to these developments was the emergence of a powerful consumer protection movement. ${ }^{153}$ The effect inside bankruptcy circles was to focus much more attention on personal bankruptcy. ${ }^{154}$

The postwar trends in corporate bankruptcy also contributed to this shift in attention. During the I930s, corporate bankruptcy had taken center stage as Douglas and other progressives excoriated the dominance of Wall Street bankers and lawyers in corporate reorganization practice. In the postwar era, by contrast, corporate bankruptcy quickly faded as an issue for most progressive scholars. The most obvious reason was a remarkable drop in corporate bankruptcy filings. In 1939 , the first year of the Chandler Act, ${ }^{155} 577$ debtors filed for Chapter $\mathrm{X}$, the provisions designed for large corporations. One year later, the number dropped to $29 \mathrm{I}$, and by the mid-I940s, most years saw fewer than a hundred new filings. ${ }^{156}$ After so many firms had failed during the Depression, and with the markets just getting back on their feet, bankruptcy did not seem so pressing a concern. Contributing to the lack of urgency was the fact that William Douglas and his fellow progressives had solved precisely the problems against which they had railed. ${ }^{157}$ The progressives' great concern had been Wall

dramatically, from $11,05 \mathrm{I}$ in 1945 to 97,750 in 1960 and to 178,202 in 1970 . See STANLEY \& GIRTH, supra note 83 , at 25 tbl.3-I.

153 Nationally, the consumer advocacy movement was often associated with Ralph Nader and his allies. Consumer advocates scored important victories in commercial law with the enactment of such legislation as the Consumer Credit Protection Act of 1968, Pub. L. No. 90-321, 82 Stat. I46 (codified as amended at I5 U.S.C. \$\$ I60I-I693r (Supp. IV I998)), and state provisions based on the Uniform Consumer Credit Code promulgated by the National Conference of Commissioners on Uniform State Laws in 1974 , UNIF. CONSUMER CREDIT CODE, 7 A U.L.A. I (I974).

154 Indeed, Bill Whitford has suggested that personal bankruptcy has become one of the few remaining strongholds of individualized justice for consumers, given the trend toward class-action consumer litigation. See William C. Whitford, The Ideal of Individualized Justice: Consumer Bankruptcy as Consumer Protection, and Consumer Protection in Consumer Bankruptcy, 68 AM. BANKR. L.J. 397, 402-03 (I 994).

155 For a discussion of the Chandler Act, see note 67

156 From 1939 to 1953 , the numbers of Chapter X cases filed were as follows:

\begin{tabular}{|c|c|c|c|c|c|}
\hline 1939 & 577 & I 944 & 95 & 1949: & II 3 \\
\hline I 940 & 291 & I 945 & 70 & I 950: & 102 \\
\hline I 94I & $29 I$ & I 946 & 60 & r95 I: & 75 \\
\hline I 942 & 165 & 1947 & 94 & I952: & 64 \\
\hline 1943 & 109 & I948 & 105 & I953: & 61 \\
\hline
\end{tabular}

See Hearings on S. 235 and S. 236 Before the Subcomm. on Improvements in Judiciary Machinery of the Senate Comm. on the Judiciary, 94th Cong. 778 (1975) [hereinafter 1975-1976 Senate Hearings].

157 Because filing for bankruptcy under Chapter $\mathrm{X}$ meant that managers of large firms would lose their jobs to an independent trustee, such managers avoided Chapter $\mathrm{X}$ for as long as possi- 
Street's dominance of corporate reorganization. After Congress adopted the Chandler Act of 1938, the Wall Street bankers and lawyers quickly disappeared from corporate bankruptcy. Gone were the days when managers, bankers, and the elite bar met in fancy hotels to decide the fate of large, troubled corporations.

Thus, by the Ig6os, the bankruptcy villain had changed. Wall Street had declined as a serious threat in bankruptcy, and progressive scholars were increasingly concerned about the enormous consumer credit industry. Vern Countryman's career nicely reflected this shift. In 1972 , Douglas asked Countryman whether the I930s SEC Report had inspired any thoughts on corporate bankruptcy. "I read the eight volumes of the SEC Protective Committee study before I reported to you for duty," Countryman responded, "but no books or articles resulted."158 Instead, Countryman focused his scholarly energies on the plight of consumer bankrupts.

Like Douglas before him, Vern Countryman almost invariably sought to convert his proposed reforms into concrete legislative action. Perhaps his most cherished reform was one that he designed to address a concern he called "improvident credit extension."159 The inspiration for Countryman's proposal was the inclusion in the Uniform Commercial Code of a provision precluding the enforcement of "unconscionable" terms in consumer contracts. ${ }^{160}$ Countryman argued that Congress should disallow the claims of any creditor who had extended credit to a debtor who later filed for bankruptcy and whom the creditor could not reasonably have expected to pay. ${ }^{161}$ Although Countryman later persuaded the 1973 Bankruptcy Commission to include his provision in proposed legislation, Congress never adopted it. ${ }^{162}$ More successful were Countryman's efforts to expand the bankruptcy discharge in I970. Countryman played a prominent role in the campaign

ble. In later years, they increasingly sought to invoke the less onerous provisions of Chapter XI, which was designed for smaller firms. See Skeel, supra note 30, at 1341-42.

158 Letter from Vern Countryman to William Douglas (Nov. 15, 1972) (on file with the Library of Congress, Douglas Papers, Container No. Iri 8 ).

159 Countryman, supra note 68, at I-7.

160 See id. at 9 ("This proposal [an earlier version of Countryman's ultimate proposal] was modeled on $\$ 2-302$ of the Uniform Commercial Code ...."). Under U.C.C. \$ 2-302, courts are authorized to invalidate "unconscionable" sales transactions. See U.C.C. \$ 2-302 (I997).

161 Countryman proposed that lawmakers define an "improvident credit extension" as "a contractual extension of credit to a debtor where it cannot reasonably be expected that the debtor can repay ... in view of the circumstances of the debtor at the time credit was extended as these circumstances were known to the creditor or would have been revealed to him on reasonable inquiry prior to the credit extension." Countryman, supra note 68, at 23.

162 See I973 COMMISSION REPORT, supra note $12 \mathrm{I}$, pt. I, at 22 (noting that the proposed \$ 4 403 (c) would disallow any "unconscionable consumer claim"). Countryman continued to advocate the provision throughout the lengthy legislative process that led to the 1978 Code. See, e.g., I975I976 Senate Hearings, supra note 156 , at 1037 (statement of Vern Countryman) (arguing for disallowance of claims based on improvident credit extensions). 
to pass legislation that precluded creditors from bringing state law actions challenging a debtor's discharge after the bankruptcy case had ended. ${ }^{163}$

In addition to devoting more of his attention to personal bankruptcy than Douglas, Countryman also took a crucially different stance on the appropriate scope of governmental oversight. Recall that Douglas had enthusiastically supported the I932 proposal to give bankruptcy officials the authority to delay or condition a debtor's discharge. ${ }^{164}$ Unlike Douglas, whose views reflected New Deal confidence in paternalistic governmental intervention, Countryman vehemently opposed efforts to limit debtors' access to a discharge. When the consumer creditor industry began to promote legislation to force more debtors into Chapter I3, Countryman analogized the effort to the I 932 proposal - the same reform Douglas had supported - and lambasted the earlier legislation as, "to my knowledge, the only proposed bankruptcy legislation in this country to be characterized by witnesses as "UnAmerican." '165 Although Countryman thought that creditors should encourage debtors to use Chapter I3, he also believed that debtors rather than courts should be the ones to make this decision. ${ }^{166}$

It is important to emphasize that Countryman did not simply ignore corporate bankruptcy. To the contrary, he weighed in on the subject throughout his career. Two of his most famous articles - his discourse on executory contracts and his examination of the role of state law in bankruptcy - addressed issues relevant to both corporate and personal bankruptcy.167 Countryman also defended both the SEC's role in bankruptcy and the preservation of the absolute priority rule in corporate reorganization. ${ }^{168}$ In the hearings that led to the enactment

163 Prior to the 1970 amendment, Pub. L. No. 9I-467, 84 Stat. 990 (I970), creditors often challenged debtors' bankruptcy discharges in state court, alleging that the creditors' claims should not be treated as discharged due to fraud by the debtors. Critics complained that the suits amounted to harassment, and many debtors could not afford to contest them. The I970 amendment required that challenges to a debtor's discharge be brought in the bankruptcy court before the conclusion of the case. See id. at 992-93. For a background discussion of the amendment and its history, see Vern C. Countryman, The New Dischargeability Law, 45 AM. BANKR. L.J. I (I97 I).

164 See supra pp. 1086-87.

165 Countryman, supra note 89, at 821 (quoting Joint Hearing on S. 3863 Before Subcomms. of the House and Senate Judiciary Comms., 73d Cong. 546, 743 (I932)).

166 See Vern Countryman, The Bankruptcy Boom, 77 HARV. L. REV. I 452, I460 (I964) (describing the voluntary wage earner plan in Chapter XIII - the predecessor to current Chapter I 3 - as a "solution[] available under the Bankruptcy Act which [is] preferable, from the creditors" viewpoint, to a straight bankruptcy proceeding").

167 See Countryman, supra note 6 (discussing the role of executory contracts in both corporate and personal bankruptcy law); Vern Countryman, The Use of State Law in Bankruptcy Cases (pts. I $\mathcal{E}$ 2), 47 N.Y.U. L. REV. 407, 63I (I972) (arguing that Congress should override state law on various bankruptcy issues, rather than simply adhering to state law in bankruptcy).

168 See Smith, supra note 2, at 4. 
of the 1978 Code, Countryman had several complaints about the 1973 Commission's proposal to relax the absolute priority rule: ${ }^{169}$

The best that can be said for [the Commission's] formulation is that the "fair and equitable" standard [a term of art for the absolute priority rule] is now surrounded by weasel words. .. . It seems apparent that the [1973] Commission's hope was that the court will operate in this leeway to increase the valuation on which the plan is based and thus to increase the participation of junior interests .... This proposal is not likely to produce more sound and successful reorganizations and I urge the Subcommittee to return to the original "fair and equitable" test without the leewayproviding verbiage. ${ }^{170}$

Countryman's enthusiasm for absolute priority and the SEC underscores his link to William Douglas. But Countryman's principal concern throughout his career was personal bankruptcy, and in this he ventured beyond his mentor's footsteps.

2. A Lifelong Alliance with the Bankruptcy Bar. The second distinction between Countryman and his mentor was in their relationships with the bankruptcy bar. As we have seen, Douglas almost gleefully attacked both the general bankruptcy bar and the elite corporate reorganization bar. ${ }^{171}$ His vision for personal and small business bankruptcy would have destabilized existing practice, at least for bankruptcy lawyers, and Douglas launched an all-out assault on the Wall Street lawyers who had dominated large-scale reorganization for decades.

The relationship between Vern Countryman and the bar could not have been more different. Although Countryman criticized certain aspects of bankruptcy practice, such as bankruptcy judges' involvement in both judicial and administrative issues under the old Act, ${ }^{172}$ he worked closely with the bankruptcy bar for decades. By the early ig6os, he was a leading presence on the American Bar Association's

169 The 1973 Commission proposed to retain the absolute priority rule, but to relax the valuation procedure by permitting plans that gave junior creditors an interest as long as there was a "reasonable basis for the valuation" and a "reasonable probability' of fully compensating prior claims and interests." I973 COMMISSION REPORT, supra note I21, pt. II, at 255 (explaining proposed $\$ 7$-303). As finally enacted, the 1978 Code went further, and waved off absolute priority altogether for any class that voted in favor of the plan. See supra p. 1097.

170 1975-1976 Senate Hearings, supra note I56, at 1043. Interestingly, given the recent debate over the so-called new value exception to the absolute priority rule, Countryman also sharply criticized the 1973 Commission's proposal to permit existing shareholders to participate in a reorganization if they "make a contribution which is important to the operation of the reorganized debtor." Id. at 1044 (quoting $\$ 7-303$ of the Bankruptcy Act) (internal quotation marks omitted).

171 See supra pp. 1086-87, 1090.

$172 \mathrm{He}$ also was willing to criticize the judges themselves, at least in the aggregate. "There are some very good presently incumbent bankruptcy judges," Countryman told Congress in 1977, "but there are also some terrible ones. . . We really need to elevate the status of this court so that we can attract better people." Hearings Before the Subcomm. on Civil and Constitutional Issues of the House Comm. on the Judiciary, 95th Cong. 254 (I977) (statement of Vern Countryman). 
bankruptcy committees, and he joined the bankruptcy bar's principal reform organization, the National Bankruptcy Conference (NBC), at roughly the same time. Countryman later became vice-chair of the Conference, and he testified before Congress on the NBC's behalf at hearing after hearing. ${ }^{173}$

Countryman's close ties to the bankruptcy bar are especially surprising considering that both his seedtime with William Douglas and the defiant stance he took in the loyalty cases of the I950s seemed to align him squarely against the established bar. ${ }^{174}$ Several factors may help to make sense of Countryman's rapprochement with practicing attorneys. The first is the status of the bar itself. As I describe in the preceding section, the Chandler Act of I 938 devastated the elite corporate reorganization bar, ushering Wall Street out of bankruptcy altogether. Within a few years, corporate reorganization practice lost all of its cachet and descended to the status that had previously been occupied only by the general bankruptcy bar. ${ }^{175}$ The most prominent Wall Street law firms abandoned the practice. A disproportionate number of the lawyers who filled the gap, and rose to the top of the practice in the I950s, were Jewish. ${ }^{176}$ There was an obvious reason for this development. The white-shoe New York firms still discriminated quite explicitly against Jews, forcing many bright Jewish law school graduates to look elsewhere for jobs. Given that bankruptcy was a relatively sophisticated practice, and one that did not exclude Jews, it was an obvious choice.

Unlike the elite Wall Street lawyers of Douglas's day, then, the bankruptcy lawyers that Countryman encountered were themselves outsiders in the legal profession. One can easily imagine why a scholar who had risked his academic career to defend outsiders would be sympathetic to a bar whose leaders also had faced exclusion. In both instances, the reason for persecution may have been the same - many observers suspect that anti-Semitism played a role in the loyalty prose-

173 See, e.g., id. at 238 (memorandum of the National Bankruptcy Conference, represented by, among others, Vern Countryman, vice-chair).

174 In criticizing loyalty tests for lawyers in 1953 , for instance, Countryman pointed out that "with very few exceptions, these tests have been imposed by, or at least at the instance of, the bar itself." Countryman, Loyalty Tests, supra note 9, at I49. He complained that "in this instance the hysterical men [calling for loyalty tests] have had the full support of the American Bar Association." Id.

175 I have described this transition in detail elsewhere. See Skeel, supra note 6I.

176 See generally Leonard M. Rosen \& Jane Lee Vris, A History of the Bankruptcy Bar in the Second Circuit, in THE DEVELOPMENT OF BANKRUPTCY \& REORGANIZATION LAW IN THE COURTS OF THE SECOND CiRCuit OF THE UNited STATES 155, 18 I (United States Courts for the Second Circuit Committee on History and Commemorative Events ed., I 995) (referring to the growth of the "smaller, predominently [sic] Jewish firms specializing in bankruptcy"). 
cutions, the defendants of which were often Jewish, ${ }^{177}$ just as it did in shaping the bankruptcy bar.

A second factor tying Countryman to the bankruptcy bar may have been the doctrinal bent in his scholarship. Douglas was by nature a visionary who had little in common with the doctrinally oriented scholars of his time, such as Harvard's James McLaughlin. Although Douglas could adapt his mind to careful doctrinal analysis when necessary, his heart lay in idol-smashing reform. Countryman, by contrast, found doctrinal analysis far more congenial. ${ }^{178}$ Even his activism in the loyalty cases was firmly grounded in arguments based on constitutional doctrine, given the goal of persuading courts to acquit the defendants. In his affinity for doctrinal analysis, Countryman had much more in common with the practicing bar than did Douglas.

Third, at an important juncture in his career, Countryman himself left academia to become a practicing lawyer. After he resigned from Yale in I955, Countryman joined the Washington, D.C. law firm of Shea, Greenman \& Gardner as a partner, and pursued private practice for the next four years. This stint as a practicing lawyer brought him into close contact with the bar, and it was during this time that Countryman began his formal involvement in ABA activities. Both Countryman and the National Bankruptcy Conference figured prominently on the National Bankruptcy Review Commission, which set the reform process in motion in the early 1970 , and both made frequent appearances at subsequent legislative hearings.

Finally, during Countryman's career the most prominent bankruptcy lawyers - particularly those associated with the National Bankruptcy Conference - were unusually interested in promoting reform. To be sure, these lawyers stood to benefit, and did benefit, from the changes eventually wrought by the 1978 Code. But the principal motivation for many was a deep commitment to internal reform - to cleaning up the disreputable aspects of bankruptcy practice. ${ }^{179}$

177 See KaLMAN, supra note 134 , at I 32.

173 Prior to Countryman, doctrinal bankruptcy scholarship was often viewed as conservative in nature. Countryman was arguably the first scholar to wed the doctrinal approach with unmistakably progressive instincts. This combination is now so pervasive that, in a recent account of the debates between progressives and law and economics-oriented bankruptcy scholars, Douglas Baird refers to the progressives, without irony, as "traditionalists." See Douglas G. Baird, Bankmuptcy's Uncontested Axioms, 108 YALE L.J. 573, 576 (I998).

179 For a brief description of the bar's campaign to reform bankruptcy law, see Rosen \& Vris, cited above in note I 76 , at $182-85$. The reformers' principal concern was to alter the role of the bankruptcy judge, so that judges no longer performed both administrative and judicial functions. Many observers believed that judges' involvement in administrative procedures such as the initial creditors' meeting made it impossible for them to render truly objective rulings when judicial issues arose. For an important discussion of the concerns with the then existing approach by a leader in the reform effort, see George M. Treister, Bankmuptcy Jurisdiction: Is it Too Summary?, 39 S. CAL. L. REV. 78, 85-90 (1966), which discusses perceived conflicts of interest. 
In retrospect, it is difficult to determine which of the factors $\mathbb{I}$ have noted are causes, and which are effects, of Countryman's ties to the bankruptcy bar. Perhaps Countryman would have become a member and an ally of the National Bankruptcy Conference even if he had never resigned from Yale and entered private practice. Perhaps his doctrinal bent was a result of, rather than a basis for, his affinity for the bar. Whatever the sequence, the important point is that Countryman clearly viewed the practicing bar as friend rather than foe. In this respect, as in his focus on personal bankruptcy, Countryman charted a very different course from the one that Douglas had taken.

3. The Rise of Law and Economics. A final development marking the transition from Douglas to Countryman is the emergence of the law and economics movement in the r97os. The early law and economics movement was instrumentalism writ large. Law and economics scholars assume that individuals tend to pursue their own selfinterest and will alter their behavior in response to legal rules. According to these scholars, legal rules should be designed to promote the efficient allocation of resources. In bankruptcy, the earliest law and economics analyses suggested that lawmakers could counteract the surge in personal bankruptcy filings by reducing the amount of property that debtors could exempt from creditors. Making bankruptcy less generous, the reasoning went, would discourage debtors from discharging their obligations. 180

With its emphasis on instrumentalism, law and economics pursues a theme that dates back to Douglas and other early legal realists. Recent progressives have almost universally rejected the law and economics approach, however. These scholars criticize law and economics analysis for relying on simple but unsubstantiated assumptions about the behavior of debtors and others. ${ }^{181}$ Because law and economics scholarship does not account for the intricate factual context in which actual debtors and creditors interact, its conclusions are inherently suspect.

Although law and economics entered the bankruptcy literature late in his career, Countryman shared the skepticism of current progressives toward its methods and simplistic prescriptions. An exchange between Countryman and Douglas that dates back to the earliest years

180 See, e.g., William H. Meckling, Financial Markets, Default, and Bankruptcy: The Role of the State, 4I LAW \& CONTEMP. PROBS. I3, 27 (I977) ("Changes in bankruptcy law which lower the costs or raise the benefits to debtors of one of [the bankruptcy or informal settlement options] . will without question increase .. the total number of debtors who elect [that option].").

181 For example, Teresa A. Sullivan, Elizabeth Warren, and Jay Lawrence Westbrook have complained that to Meckling and other early economics-based scholars, the "bald assertion that manipulating the laws would produce predictable effects in debtor behavior . . was evidently so obvious as to require no empirical substantiation." SULLIVAN, WARREN \& WESTBROOK, supra note 82 , at 232 . 
of Countryman's career foreshadows much of the hostility that progressive scholars have for the reductive, and often politically conservative, tendencies of law and economics scholarship. After returning from a I 948 visit to the University of Chicago, whose Aaron Director is considered by some as the father of law and economics, Countryman did not mince his words:

I'm afraid I don't share your high opinion of the place. ${ }^{182}$ In my judgment it's nothing but an indoctrination school and the doctrine which it sells is the classical economic theory of Henry Simon as expounded by his successor, Aaron Director. My objection is not so much that I consider it poor doctrine - which I do - as that everyone at Chicago seems to preach it. ${ }^{183}$

During his years at Harvard Law School, Countryman witnessed firsthand the rise and increasing dominance of law and economics in bankruptcy scholarship. The pioneering influence was Thomas Jackson, a young Stanford law professor who employed law and economics methodology in his "creditors' bargain" theory of bankruptcy law. ${ }^{184}$ As articulated by Jackson and his frequent co-author, Douglas Baird, and applied to a wide range of bankruptcy issues, the creditors' bargain theory argues that the goal of bankruptcy is to provide a collective solution to financial distress. By forcing creditors to halt their individual collection efforts, bankruptcy law prevents them from engaging in a "race to the courthouse," with creditors dismembering a potentially viable firm in their zeal to collect what the debtor owes them. Bankruptcy should not do more than this, however. In particular, bankruptcy should not alter nonbankruptcy law except to the extent necessary to facilitate an orderly, collective insolvency proceeding. According to Baird and Jackson, deviations from nonbankruptcy law for other purposes would lead to costly, inefficient jurisdictional battles between parties who fare better in bankruptcy and those who prefer their entitlements under state law. By the mid-I980s, the creditors' bargain model dominated bankruptcy discourse. In 1986, another prominent law and economics scholar announced in a review of Baird's and Jackson's bankruptcy casebook that the creditors' bargain

182 Douglas's optimism about the University of Chicago Law School was based on his friendship with Robert Hutchins, a fervent legal realist who left Yale to become President of the University of Chicago in 1929.

183 Letter from Vern Countryman to William O. Douglas (Oct. 28, I948) (on file with the Library of Congress, Douglas Files, Container No. I I 8).

184 Jackson first articulated the creditors' bargain theory in Thomas H. Jackson, Bankruptcy, Non-Bankruptcy Entitlements, and the Creditors' Bargain, 9I YALE L.J. 857, 859-7 I (I982). He co-authored several subsequent elaborations of the theory with Douglas Baird, see, e.g., Douglas G. Baird \& Thomas H. Jackson, Corporate Reorganizations and the Treatment of Diverse Ownership Interests: A Comment on Adequate Protection of Secured Creditors in Bankruptcy, 5 I U. CHI. L. REV. 97 (I984), and eventually published the analysis as a book, THOMAS H. JACKSON, THE LOGIC AND LIMITS OF BANKRUPTCY LAW (I 986). 
theory had "set the terms of the scholarly debate for the next decade."185 Although other scholars grumbled, ${ }^{186}$ law and economics had become, and has remained, the most prominent methodology in bankruptcy scholarship.

The creditors' bargain model embodies precisely the characteristics that Countryman had complained about in his letter to Douglas decades earlier. Baird and Jackson assume, for example, that creditors operate in competitive credit markets and that changes in bankruptcy law will therefore have a direct effect on both their willingness to extend credit and the interest rates they charge - otherwise, it would not be so important that bankruptcy law replicate nonbankruptcy law. Baird's and Jackson's confidence in market forces comes straight from the classical economics that Countryman had criticized after his visit to the University of Chicago. Countryman remained deeply skeptical of these kinds of arguments, and their reliance on theory rather than empirical data, throughout his career. In one of his last publications, a I 985 article on preferential transfers, Countryman took direct aim at Baird and Jackson, both of whom were participants in the symposium for which he wrote the article. The theoretical approach of Baird, Jackson, and other law and economics scholars to an issue like preferential transfers, Countryman complained, was inadequate:

[The assumptions of these scholars leave them] free from the burden of scrutinizing the vast judicial output that reveals how the current preference law is being administered - a subject in which they evince little interest.... I confess to sharing the reaction of Professor Richard Markovitz after he had listened to another preacher of the true gospel. $\mathrm{He}$ suggested that the answer to the question, "How many Chicago economists does it take to change a lightbulb?" was: "None. If it needed changing, the market would have changed it already."187

Countryman's views on the Harvard Law School appointments process provide additional evidence that his hostility toward law and economics analysis did not mellow over time. After Thomas Jackson spent one year as a visiting professor at Harvard from I 985 to Ig86, the law school voted to give him a permanent position. By all accounts, Countryman fiercely opposed the appointment. ${ }^{188}$ Countryman viewed law and economics as a pernicious influence on policy debates in bankruptcy, and he refused to support the scholar whose work

185 Robert E. Scott, Through Bankruptcy with the Creditors' Bargain Heuristic, 53 U. CHI. L. REV. 690, 692 (1986).

186 See, e.g., Warren, Bankruptcy Policy, supra note II 4, at 8 I I-I2 (quoting this claim and suggesting that law and economics analysis, though "seductive," is misguided).

187 Vern Countryman, The Concept of a Voidable Preference in Bankruptcy, 38 VAND. L. REV. 713,827 (1985) (citations omitted).

188 See, e.g., Telephone Interview with Maura Kelly, Assistant to Vern Countryman (Nov. I2, I999). Jackson left Harvard to become Dean of the University of Virginia School of Law in I 988. 
had played so central a role in bringing this methodology to bankruptcy.

Unlike Douglas, then, who had relied on instrumental assumptions in his own work on personal and small business bankruptcies, Countryman strongly rejected the new instrumentalism. I explain below that this hostility to law and economics scholarship has become an important element of the scholarship of Elizabech Warren and other recent progressives.

\section{B. Tracing the Threads to Current Progressive Scholarship}

Each of the factors that I consider - the emphasis on personal rather than corporate bankruptcy, the close ties to the bankruptcy bar, and the hostility to law and economics analysis - has come to define progressive bankruptcy scholarship. An important effect has been to displace several elements of the early progressive vision of bankruptcy, and to produce the surprising differences between the work of William Douglas and that of Elizabeth Warren and other recent progressives. This section considers how each of the characteristics emphasized in the previous section manifests itself in the work of Warren and other current progressives.

The parallels between Countryman and Warren are most obvious in their shared emphasis on personal bankruptcy. For both, the bete noire is the consumer credit industry, and its efforts since the Ig6os to force more debtors to make payments under a rehabilitation plan rather than receive an immediate discharge. In response to the credit industry's calls in the Ig6os for stricter bankruptcy laws, Countryman argued that creditors' standards for issuing credit were far too lax. ${ }^{189}$ Subsequent progressive scholars continue to sound these themes, and to argue that debtors' access to the bankruptcy discharge must be protected.

This emphasis on personal bankruptcy has had an important indirect effect on progressive scholars' views of corporate bankruptcy. As described in the last section, Countryman's passion for personal bankruptcy caused him to de-emphasize his stance on corporate bankruptcy issues. In response to the increasing importance of corporate bankruptcy in recent years, subsequent progressives have shown much more interest in this area, and many seem to have projected their views on personal bankruptcy into the corporate context. Much as they emphasize the fresh start for individual debtors, current progressives similarly insist that corporations should be reorganized rather

139 See, e.g., Countryman, supra note 68 , at $5-6$ ("[T]here is evidence . . that institutional credit extenders will often overcommit the debtor even when they have accurate credit [information]."). 
than liquidated whenever possible. ${ }^{190}$ Progressive scholars have therefore applauded the changes wrought by the 1978 Code: its kinder, gentler version of the absolute priority rule; its assumption that a debtor's managers rather than a court-appointed trustee should continue to run the firm in bankruptcy; and its generous treatment of attorneys' fees. Although some progressive scholars - notably, Elizabeth Warren ${ }^{191}$ have kept the differences between personal and corporate bankruptcy firmly in view, many tend to treat the two contexts as interchangeable. Insights carried over from personal bankruptcy, and the commitment to a fresh start, figure prominently in progressive scholars' corporate bankruptcy analysis. Perhaps the most dramatic example of this blending of contexts is an article suggesting that corporate bankruptcy should be analogized to "group therapy."192

On the second factor, Countryman's affinity for the bankruptcy bar, Elizabeth Warren and other recent progressives have retained the close ties. Rather than challenging the bar, as Douglas did, current progressives closely ally themselves in policy debates with bankruptcy lawyers and organizations such as the National Bankruptcy Conference. If anything, recent progressives' commitment to flexible reorganization rules may have strengthened the connection by removing an important source of conflict between the practicing bar and earlier progressives. Whereas Countryman at best tolerated the shift to Chapter II, current progressives actively embrace the more malleable reorganization regime.

With respect to the third factor, the rise of law and economics, current progressives remain just as hostile as Countryman himself. In personal bankruptcy, this has meant a vigilant defense of the fresh start, at times to the exclusion of other perspectives. Gone is any serious suggestion that bankruptcy should be used instrumentally to shape debtors' behavior. The occasional exceptions to this stance have a distinctly populist flavor. In defending the recent National Bankruptcy Commission, for example, Elizabeth Warren emphasizes that the

\footnotetext{
190 See, e.g., Gross, sup; ${ }^{2}$ note 22, at I29 (arguing that "rehabilitation is facilitated by curtailing creditors' options and is justified because debtor rehabilitation trumps creditor choice"); Warren, Bankruptcy Policy, supra note II 4, at 787 ("Chapter II of the Bankruptcy Code gives bankrupt businesses another opportunity to succeed .... [T] he revival of an otherwise failing business also serves the distributional interests of many who are not technically 'creditors' but who have an interest in a business's continued existence.").

191 See, e.g., Warren, supra note 96, at 34I ("Consumer bankruptcy policy rightly concerns itself with the fresh start in ways that are not nearly so pressing for corporate debtors. ... Analogies between the two may sometimes be apt, but the circumstances differ sufficiently to justify discrete policy discussions.").

192 Donald R. Korobkin, Rehabilitciting Values: A Jurisprudence of Bankruptcy, 9I COLUM. L. REV. $71 \%, 722$ (1991). Korobkin characterizes corporate bankruptcy as "creating conditions for a discourse in which values of participants may be rehabilitated into a coherent and informed vision of . . the enterprise." Id. at 789 .
} 
Commission's proposals would curb abuses of the bankruptcy law by wealthy debtors while protecting more traditional debtors' fresh start. ${ }^{193}$

In corporate bankruptcy, the influence of law and economics scholarship has given progressive scholars still another reason to defend a "fresh start," or reorganization-based, view of Chapter II. Law and economics scholars, preoccupied with deterring inefficient behavior by debtors and their managers, tend to call for strict enforcement of creditors' priority rights, even when this practice diminishes the likelihood of reorganization. ${ }^{194}$ More recent work has taken this impulse further, and suggests that Congress should replace the current Chapter I I with market-driven, liquidation-based alternatives. ${ }^{195}$ In response to this literature, which progressive scholars view as creditor-oriented and conservative, they have dug in their heels. They, along with the practicing bar, fiercely defend the existing framework.

The methodological response of progressive scholars to the law and economics movement is at least as striking as their rejection of its policy recommendations. As law and economics pervaded the literature, an obvious response would have been to articulate a competing normative theory of bankruptcy. Rather than suggesting such a theory, however, several leading progressive scholars have focused on empirical work. The most prominent illustration is the extensive study of personal bankruptcy by Elizabeth Warren and her co-authors ${ }^{196}$ - a study that has led both to a second personal bankruptcy study ${ }^{197}$ and to an investigation of business bankruptcy. ${ }^{198}$ This focus on empirical work is very much in the spirit of Countryman's work. Countryman long emphasized the need for empirical data and criticized its absence in most law and economics scholarship. ${ }^{199}$ Subsequent progressive

193 See Warren, A Principled Approach, supra note r22, at $49 \mathrm{I}-506$.

194 The pioneering work in the r 980 os of Douglas Baird and Thomas Jackson initiated this trend. Baird's and Jackson's "creditors' bargain" model called for strict compliance with state law priority rules. See, e.g., JACKSON, supra note I84; Baird \& Jackson, supra note I84.

195 See supra note III. The most recent analysis by law and economics scholars focuses on the possibility that firms could devise their own bankruptcy rules by contract rather than depending entirely on state-supplied bankruptcy laws. See generally Alan Schwartz, A Contract Theory Approach to Business Bankruptcy, 107 YALE L.J. 1807, I808-09 (I998) (developing a model of bankruptcy contract that could be adjusted to reflect a debtor's arrangements with subsequent creditors); see also Lynn M. LoPucki, Contract Bankruptcy: A Reply to Alan Schwartz, Iog YALE L.J. 3 I 7 (offering a sustained critique of Schwartz's model).

196 SULLIVAN, WARREN \& WESTBROOK, supra note 82.

197 Teresa A. SUllivan, Elizabeth WARREN \& JAY L. WEStbroOK, THE Fragile MIDDLE CLASS: AMERICANS IN FINANCIAL CRISIS (2000).

198 See Warren \& Westbrook, supra note 80, at I258 (describing their projected business bankruptcy study).

199 See generally SULLIVAN, WARREN \& WESTBROOK, supra note 82, at 265 n.8 ("Vern Countryman is another scholar who has long lamented the absence of useful data in the bankruptcy area and who has been wary of economic models with no data to back them up."). 
scholarship continues the critique, seeking to remedy the lack of empirical data. ${ }^{200}$

In summary, current progressive scholars follow Vern Countryman's cues in each of the areas that I consider. They continue to place particular emphasis on personal bankruptcy; they have retained close ties to the bankruptcy bar; and they continue to criticize the work of law and economics scholars. In personal bankruptcy, these positions have inspired a redoubled commitment to debtor protection and a distaste for proposals that are designed to shape debtor behavior. Both of these commitments closely parallel Countryman's own views. In corporate bankruptcy, by contrast, current progressive scholars take a very different stance than Countryman does. Whereas Countryman continued to defend SEC oversight and strict enforcement of the absolute priority rule, his successors embrace the far more flexible regime embodied in Chapter II.

The evolution from Douglas through Countryman to Warren and the present has taken progressive bankruptcy scholarship far from the concerns of earlier progressive scholars. The question that remains is what to make of these developments.

\section{TwO STORIES ABOUT THE PROGRESSIVE LEGACY}

As we have seen, the course of progressive bankruptcy scholarship in the past seventy years provides a vivid illustration of the influence that one generation of scholars exerts on the next. Almost as intriguing as the threads that link Douglas to Countryman, and Countryman to Warren and other current progressives, is the fact that progressive thinking seems, in some respects, to have reversed its course. The work of Vern Countryman serves as a pivot point between William Douglas and the sometimes different concerns of progressives today.

This Part attempts to make sense of these developments. I argue that, in both personal and corporate bankruptcy, one can tell two stories about the evolution of progressive scholarship. On the one hand, the optimistic account suggests that progressive scholars have simply responded to changes in markets and other background institutions and that current progressives' vision of bankruptcy reflects the same core values as their predecessors held. The pessimistic story, on the other hand, worries that important concerns may have been lost, or at

200 Progressive scholars have tended to rely on traditional expirical methods - - such as the use by Sullivan, Warren, and Westbrook of data gathered from bankruptcy filing documents and interviews - a strategy quite similar to William Douglas's earlier approach. Law and economics scholars (and economists), by contrast, have focused on mathematical analysis of stock prices and other precisely quantifiable data. 
least obscured, in the translation of progressive values from one generarion to the next. 201

In the context of personal bankruptcy, I find the optimistic story quite compelling. Although the optimistic story also proves plausible for corporate bankruptcy, the grounds for accepting the pessimistic story appear stronger. An important progressive criticue seems to bave disappeared, and I outline what that critique might look hike if progressive scholars were to pick up that thread - right where Vern Countryman left it.

\section{A. An Optimistic View of Progressive Thinking on Personal Bankmptcy}

The pessimistic story about progressive thinking on personal bankruptcy would go something like this: in the beginning, the progressives developed a careful, nuanced view of the proper role of personal bankruptcy. Although Douglas was wary of creditor overreaching and saw bankruptcy as a crucial safety valve for those in financial distress, he also believed that bankruptcy law could be used to encourage fiscal responsibility on the part of future debtors. ${ }^{202}$ A successful bankruptcy system would thereby diminish the need for bankruptcy relief. Over the years, progressive bankruptcy theory has lost its nuance. IMany current progressives are so concerned with fending of the consumer credit lobby, and with protecting debtors' access to bankruptcy, that they have little to say about anything else.

Although progressive thinking on bankruptcy does seem to have simplified its goals in some respects, the optimistic account offers a compelling explanation for this and other trends in current progressive scholarship. Part of the explanation lies in Douglas's work itself. Although Douglas is widely remembered as one of the most liberal Supreme Court Justices of the century, his early views on bankruptcy were in many respects quite conservative. ${ }^{203}$ Douglas's early work often focused less on reining in creditors than on influencing debtors' behavior. Given the increasingly important need to rein in creditors, it

201 I have borrowed the term "translation" from Lawrence Lessig's influential work in constitutional law. See, e.g., Lawrence Lessig; Understanding Changed Readings: Fidelity and Theory, 47 STAY. L. REV. 395, 400-OI (I995).

202 See supra p. I085.

203 Some commentators have characterized Douglas's early academic stance as a strategy of calculated neutrality designed to further his academic ambitions. See, e.g., SIMON, supra note I9, at I08 ("F]or Douglas the ambitious young assistant professor of law at Yale, pushing hard for promotion and recognition in his field of commercial law, the restraint was not surprising."). My own conclusion is that Douglas's writings accurately reflected his views in the early I930s. It is worth noting in this regard that, as reform-minded as it was, the Progressive political movement of the early Igoos was itself conservative in many essential respects. See GABRIEL KOLKO, THE TRIUMPH OF CONSERVATISM 2 (Ig67). 
is not surprising that subsequent progressive scholarship has sought to shift the balance. ${ }^{204}$

In addition, the concerns that Vern Countryman and subsequent progressives have voiced about the consumer credit industry reflect important changes in the consumer credit market. Consumer credit has exploded in recent decades, and the success of the consumer credit industry's massive lobbying effort in the past several years attests to its enormous power. ${ }^{205}$ Moreover, since the late 1970s, when credit card interest rates were effectively deregulated, consumer creditors have moved down the economic ladder, lending to consumers with lower and lower incomes. ${ }^{206}$ One can debate, of course, whether these developments should be facilitated, reined in, or left alone. In the optimistic story, progressives have increased their emphasis on protecting debtors as creditors' clout has increased and as potentially vulnerable, lowerincome debtors have become an important part of the credit economy.

There are also grounds for optimism in the positive content of current progressive scholarship. Although current progressive scholars sometimes seem to do little more than attempt to fend off the critical (and often pro-creditor) insights of law and economics, the empirical focus of leading progressive scholars provides an increasingly nuanced view of debtors and the bankruptcy framework. Progressive scholars have shed new light on the effect that local legal culture has on issues such as debtors' decisions whether to seek rehabilitation or an immediate discharge. ${ }^{207}$ This work on local legal culture may provide valuable insights into the limits of legislative change. ${ }^{208}$ Recent progressive scholarship also focuses on important issues that did not figure prominently in the work of Douglas and other early progressives, such as

204 Vern Countryman's own writing is instructive in this regard. Although he referred on several occasions to Wesley Sturges's pioneering work on consumer bankruptcy, see, e.g., Countryman, supra note 68, at 6-8 (referring to Sturges as "a keen student of credit practices" and discussing Sturges's proposal for altering creditor default rights), Countryman rarely cited Douglas's scholarship in this area.

205 See Warren, A Principled Approach, supra note 122, at 486-88.

206 For an extensive discussion of this phenomenon, see David A. Moss \& Gibbs A. Johnson, The Rise of Consumer Bankruptcy: Evolution, Revolution, or Both?, 73 AM. BANKR. L.J. 3II, $332-46$ (1999).

207 Important recent contributions include Teresa A. Sullivan, Elizabeth Warren \& Jay Lawrence Westbrook, The Persistence of Local Legal Culture: Twenty Years of Evidence from the Federal Bankruptcy Courts, I7 HARV. J.L. \& PUB. POL'Y 80I (I994), and Jean Braucher, Lawyers and Consumer Bankruptcy: One Code, Many Cultures, 67 AM. BANKR. L.J. 50I (1993), which documents variation among districts in the percentage of debtors who invoke Chapter I 3 rather than Chapter 7 , see id. at 502-03.

208 For example, these variations in the percentage of debtors who seek rehabilitation rather than immediate discharge suggest that changes that give significant discretion to the bankruptcy judge - such as the 1984 amendment of Bankruptcy Code section 707(b) authorizing judges to prohibit a debtor's use of Chapter 7 if it would be a "substantial abuse," I I U.S.C. \$ 707 (I 994) will do little to alter current patterns in debtors' choice between Chapter 7 and Chapter 13. 
questions of race, gender, and ethnicity, and how they relate to bankrupicy. In their 1989 book, As We Forgive Our Debtors, Warren and her co-authors offer one of the first detailed considerations of the effect of bankruptcy on women. Their work indicates that single women who file for bankruptcy have much lower incomes than single men and are unusually vulnerable to financial hardship even after bankruptcy. ${ }^{209}$ In their forthcoming book, Warren and her co-authors consider these and other demographic variables in more detail. ${ }^{210}$ As progressive scholars continue to explore these issues, their insights should deepen our understanding of how financial distress varies across demographic groups and communities and how Congress might reform the Bankruptcy Code to account for these factors.

\section{B. A New (and Old) Progressive Critique of Corporate Bankruptcy}

As I describe above, recent progressives have embraced an approach to corporate bankruptcy that is very similar to the bankruptcy regime that Douglas attacked. As with personal bankruptcy, the shift in attitude can be explained as a response to important changes that have occurred since the I93os.

An optimistic explanation for progressives' defense of existing practice is that the excesses Douglas and others railed against have been curbed. In the I930s, Wall Street monopolized reorganization practice, to the detriment of small investors. New Deal financial reforms such as the Glass Steagall Act ${ }^{211}$ weakened the grip of J.P. Morgan and its peers on corporate finance. ${ }^{212}$ Douglas and the SEC completed the project and ushered Wall Street out of corporate bankruptcy by insisting that a trustee be appointed in large bankruptcy cases and prohibiting the debtor's current bankers or lawyers from serving as trustee or trustee's counsel. ${ }^{213}$ By the time Congress eliminated the mandatory trustee requirement in I978, Wall Street had long since disappeared from bankruptcy. With the practice no longer dominated by

209 See Sullivan, WARREN \& WeStBROOK, supra note 82, at 147, I5 r. Another prominent progressive, Karen Gross, devotes a lengthy review of As We Forgive Our Debtors to the book's findings about women debtors and calls for further feminist inquiry. See Karen Gross, Re-Vision of the Bankmptcy System: New Images of Individual Debtors, 88 MICH. L. REV. I506, I5IO-I 2 (I990).

210 See SUllivan, WARREN \& WeSTBROOK, supra note i97.

211 Banking Act of 1933 , ch. 89,48 Stat. I62 (codified as amended at I2 U.S.C. $\$ \S 24,78,377-$ 78 (I 994)) (repealed I 999).

212 The most important recent discussion of these developments is MARK J. ROE, STRONG MANAGERS, WEAK OWNERS: THE POLITICAL ROOTS OF AMERICAN CORPORATE FINANCE (I994).

213 As Douglas predicted in a letter to President Roosevelt before the Chandler Act was enacted, "the reorganization study and investigation... is now culminating in a comprehensive legislative program which should go far towards carrying into the reorganization field the high standards for finance which you have sponsored." SIMON, supra note 19, at I56. 
a small group of elite lawyers, restoring flexblity to corponate reorganization made sense. The interests of small public hinestors have also changed. Whereas earlier investors generally purchased bonds and might benefit as creditors from strict enforcement of the absolute priority rule, small investors now are more likely to invest in stock and therefore will receive nothing in bankruptcy if the lowest priority interests are cut off.

Other important legal changes further reinforced the usefuness of a flexible reorganization framework. Perhaps the most dramatic of these changes was the advent of mass torts, an issue that did not exist in earlier generations. With previously robust firms like Johns Manville and A.H. Robins struggling under the crush of thousands of lawsuits, it arguably was in all of the parties' interests to deal with the problems in a single forum. ${ }^{214}$ Bankruptcy emerged as the one formm that seemed to compensate victims, preserve the company's business, and take other distributional issues into account.

These, of course, are precisely the kinds of arguments that Warren and other progressive scholars make. They argue that current corporate bankruptcy law, with its sympathy for a debtor's managers and relaxed approach to creditors' priorities, is appropriately designed to reconcile the interests of a wide range of parties. ${ }^{215}$

The optimistic story has a powerful logic, but one can also make a strong case for a more pessimistic conclusion: progressive scholars have allied themselves too closely with the corporate bankruptcy bar. Although this sympathy for the bar is understandable, it is important to note how much the bar has changed since the push for bankruptcy reform in the ig6os. In the wake of the 1978 Code, the nation's elite firms rediscovered bankruptcy; the most prominent bankruptcy lawyers now work for many of the same big city firms that dominated corporate reorganization in the days of the early progressives. ${ }^{216}$ In view of these changes, there may still be a need for aspects of the old progressive critique - the perspective passed down from Douglas to Countryman but left behind by current progressive scholars.

\footnotetext{
214 Warren points out:

When people speak of the nightmare of the Johns Manville trust or the Eastern Airlines debacle, it is well to think of the debacle outside bankruptcy. No doubt some asbestosis claimants would have collected big judgments in full, but at some point - at the rooth claimant, or the roooth, or the 100,000th - Manville would have been out of money and the later victims would have received nothing.

Warren, Better Alternative, supra note II 4 , at 16.

215 See, e.g., Warren, supra note 96, at 343-44 (describing the goals of the business bankruptcy system with implicit approval).

216 See Rosen \& Vris, supra note 176 , at 156 (noting that 49 of the 50 largest New York firms now describe themselves as having bankruptcy expertise); id. at I85 (describing the substantial bankruptcy practices of Simpson, Thacher \& Bartlett, Shearman \& Sterling, and White \& Case).
} 
Consider the two benchmarks of the ro3os critique: banker-lawyer conflicts of interest and the status of a debtor's managers in bankruptcy. The New Deal reforms solved the most troubling conflicts problem by slamming shut the doors of bankruptcy on Wall Street. As corporate bankruptcy practices at large firms have expanded in recent years, however, new conflicts of interest have emerged. Prominent lawyers such as Harvey Miller are involved in so many of the leading cases that they often have ties to parties with potentially adverse interests. In the teslie Fay case, for instance, Niller's firm, Weil, Gotshal \& Manges, represented several significant creditors, as well as the debtor, Leslie Fay. Because Weil, Gotshal never disclosed the conflict to the court, the bankruptcy judge required the firm to pay the $\$ 800,000$ cost of the investigation that rooted out the conflict. ${ }^{217}$

The progressive response to these concerns about conflicts of interest has been surprisingly muted. During its deliberations on the current Bankruptcy Code, the National Bankruptcy Review Commission initially adopted a proposal to weaken the Code's "disinterestedness" requirement for attorneys and only later reversed itself.218 If progressive scholars were to take a vigorous stance on this issue, how might the critique look?

The most obvious step would be for progressives simply to insist on strict conflicts standards. Progressives might question, for instance, whether bankruptcy truly warrants more flexible standards than those used in other contexts. Even more interesting would be to focus on the institutional issue of who should be authorized to regulate the conflicts issue. The conflicts problem could provide a valuable opportunity to reverse one of the most remarkable effects of the 1978 bankrupicy reforms, the dramatic scaling back of the SEC's role in corporate bankruptcy. ${ }^{219}$ Before 1978 , the SEC served as the principal representative of the interests of public investors in bankruptcy. The 1978 Code culminated a long erosion of the SEC's role by sharply restricting the SEC's influence. Since I978, there has been only limited

217 See In re Leslie Fay Cos., I75 B.R. 525, 539 (Bankr. S.D.N.Y. I994).

218 The 1997 Commission initially proposed to amend the Bankruptcy Code's "disinterestedness" standard to preclude an attorney from representing the debtor only if she had a "material" conflict of interest. For discussion of these events, see Todd J. Zywicki, Mend It, Don't End It: The Case for Reiaining the Disinterestedness Requirement for Debtor in Possession's Professionals, is MISS. C. L. REV. 29 I (I998). For an argument defending more flexible standards, see Gerald K. Smith, Standards for the Employment of Professionals in Bankruptcy Cases: A Response to Professor Zywicki's Case for Retaining the Disinterestedness Requirement for Debtor in Possession's Professionals, is MIss. C. L. REV. 327 (I998). See also G. Ray Warner, Of Grinches, Alchemy and Disinterestedness: The Commission's Magically Disappearing Conflicts of Interest, 5 AM. BANKR. INST. L. REV. 423 (I997) (criticizing the proposal to relax conflict of interest standards).

219 For a detailed discussion of the Code's repudiation of the SEC and the New Deal vision of large-scale corporate reorganization, see Skeel, supra note $6 \mathrm{I}$. 
governmental oversight in bankruptcy. ${ }^{220}$ By calling for SEC regulation of the conflicts problem, progressive scholars could encourage Congress to reinvigorate the role of government oversight on troublesome bankruptcy issues. ${ }^{221}$

As with bankruptcy attorneys, one can also imagine a vigorous progressive critique of the role of managers in the failure of large corporations - especially given the widespread concerns about managers' ability to use Chapter Ir strategically. ${ }^{222}$ Rather than defending current law, which permits managers to continue to run the firm in bankruptcy, progressives might insist on close scrutiny of the managers of a failing firm. (Criticism of managers' continued role was, of course, a constant refrain of the SEC study overseen by William Douglas. ${ }^{223}$ ) As an alternative to simply leaving managers in place, Congress could authorize the SEC to determine at the start of a case whether the firm's existing managers should be retained or replaced. 224 Progressives might further call for Congress to limit managers' ability to use the bankruptcy process to derail derivative litigation against them..$^{225}$

Progressive scholars could also take a much more aggressive stance on protecting employees. Surprisingly few progressives - a prominent exception being Vern Countryman himself ${ }^{26}$ - have insisted that em-

220 Under the 1938 Chandler Act amendments, the court could not confirm a reorganization plan in a Chapter X case until the SEC had issued a report on the proposal. The 1978 Code left the SEC with little role in corporate reorganization. See id.

221 Thus, Congress might authorize the SEC to use its rulemaking process to develop conflicts rules. This delegation would diminish the ad hoc quality of the existing caselaw and would permit an ongoing response to conflicts problems. The SEC might also play a useful role in regulating claims trading and related issues.

222 The most prominent accounts (neither by legal academics) are DELANEY, supra note 103 (strategic bankruptcy), and SOBOL, supra note 106 (the A.H. Robins case). It is important to emphasize, however, that Chapter II is not a picnic for the debtor's managers. Many managers are replaced before the end of the reorganization process. See Stuart C. Gilson, Bankruptcy, Boards, Banks, and Blockholders: Evidence on Changes in Corporate Ownership and Control When Firms Default, 27 J. FIN. ECON. 355, 373-79 (1990). Nevertheless, managers clearly fare better in Chapter in than under prior law.

223 See supra pp. 1089-90.

224 Regulators have precisely this authority in bank and insurance insolvency cases (which are not governed by the Bankruptcy Code). In both contexts, there is a strong presumption that managers should be removed. See, e.g., I2 U.S.C. $\$ 18310(f)(2)(F)(i i)$ (I994). Progressives might call for a similar but less draconian approach in bankruptcy.

225 Existing bankruptcy law sharply limits the effectiveness of derivative litigation alleging that a debtor's managers have breached their fiduciary duties. Plaintiffs' attorneys who have brought litigation against the managers before bankruptcy, for instance, often abandon the litigation due to the procedural obstacles posed by bankruptcy law. I have discussed these problems at length in other work. See David A. Skeel, Jr., Rethinking the Line Between Corporate Law and Corporate Bankruptcy, 72 TEX. L. REV. 47I, 498-506 (1994).

226 See Douglas Bordewieck \& Vern Countryman, The Rejection of Collective Bargaining Agreements by Chapter II Debtors, 57 AM. BANKR. L.J. 293, 299-300 (I983). 
ployees' collective bargaining rights should be fully protected in bankruptcy. (Many, including Elizabeth Warren, suggest that these rights should be balanced against other concerns. ${ }^{227}$ ) In addition to collective bargaining rights, progressives might explore other protections for employees. One intriguing possibility, which Pennsylvania has adopted in the corporate antitakeover context, is mandatory "tin parachute" provisions that would protect employees laid off shortly after a firm's reorganization..$^{228}$

An obvious response to these suggestions - closely paralleling arguments that progressive scholars have made in the corporate law context - is that the best way to protect employees and investors is by promoting reorganization, even if this approach incidentally benefits corporate managers and the bankruptcy bar. Leaving managers of troubled firms in place encourages them to invoke bankruptcy, for instance, and smooths the way to reorganization. The reorganization in turn benefits employees and others because it keeps the firm in business. 229

Although this is a plausible defense of current progressive thinking, it is far from conclusive. First, it is hardly certain that the proposals I suggest, such as closer scrutiny of managers and greater protection of employees, would seriously interfere with reorganization. Moreover, progressives have traditionally taken the view that shifting the balance of power away from managers and toward employees is important enough to justify any chilling effect. ${ }^{230}$

227 See Warren, Bankruptcy Policy, supra note 114 , at 792 ("[T]he Code suggests that the distributional aim of bankruptcy should be tailored to the facts of the case - permitting impairment of labor contracts if it is essential for a successful reorganization and rejecting it if it is not.").

228 I5 PA. CONS. STAT. $\$ \$ 258$ I-83 (r995). The Pennsylvania provisions provide compensation for employees who are laid off within six months of a takeover. To be effective in a subsequent bankruptcy, such provisions would need to be given priority status.

229 Corporate law progressives have made similar arguments in defense of antitakeover statutes such as "other constituency" provisions that permit the managers of a firm that is the target of a takeover bid to consider factors other than stock value in deciding whether to reject the bid. Although these provisions strengthen managers' hands, progressive scholars see them as also benefiting employees and the local community. See, e.g., Lawrence E. Mitchell, A Theoretical and Practical Framework for Enforcing Corporate Constituency Statutes, 70 TEx. L. REV. 579 (I992). Corporate progressives also share with bankruptcy progressives an increasing emphasis on communitarian values. See Gross, supra note 22 (bankruptcy); Progressive Corporate LAW (Lawrence E. Mitchell ed., I995).

230 In the legislative hearings on the Chandler Act, for instance, William Douglas ignored lawyers' complaints that the mandatory trustee requirement would cause managers to avoid bankruptcy at all costs. Only a strong measure, he maintained, would solve the problems with existing law. Douglas insisted that the involvement of an independent trustee was "the keystone of th[e] program." Revision of the Bankruptcy Act: Hearing on H.R. 6439 Bcfore the House Comm. on the Judiciary, 75 th Cong. 163-64, 175-77 (1937) (statement of William Douglas). 
Second, and more interesting, the defense of current progressive thinking focuses on the time after a firm has fled for bankruptcy. ${ }^{231}$ At this point, reorganization seems to benefit non-shareholder constituencies because it keeps the firm afloat. Employees therefore keep their jobs, and the local community retains the benefits of the firm's presence. If one considers employees' perspective before the firm runs into trouble, however, the situation looks quite different. Bankruptcy rules that punish managers and thus discourage bankruptcy may actually give managers a powerful incentive to avoid financial difficulty in the first instance. A manager who knows she will be removed in the event of bankruptcy is likely to be more cautious while the firm is heaithy than one who knows her control will continue. ${ }^{2.32}$ As $I$ have shown in detail elsewhere, this is precisely what we see in nations such as Germany and Japan, whose firms place a much greater emphasis on employee job security and other non-shareholder interests than U.S. firms do. ${ }^{233}$ Outside of the United States, stringent bankruptcy laws and progressive corporate law almost always go hand in hand.

Let me emphasize that I am not trying to displace the current progressive view altogether. One can credibly argue that reorganization practice has been cleaned up and the world has changed so much since the I93os that the early progressives' concerns simply do not apply in the same way. Yet it also seems clear that contemporary progressives' ties to the corporate bankruptcy bar, their grounding in perspectives taken from personal bankruptcy, and their academic battles with the law and economics movement figure prominently in their fierce loyalty to the reorganization framework established in 1978 . This history suggests that the current reorganization framework could benefit from a different progressive critique, one that sounds more like that of William Douglas and Vern Countryman.

\section{CONCLUSION}

Vern Countryman is a remarkable figure in twentieth-century legal academia generally and in bankruptcy in particular. He was anointed early on as the heir to William Douglas, the most important progressive bankruptcy scholar of the century. Thereafter, he left his mark on every corner of bankruptcy theory and practice. Countryman's definition of an executory contract has served as the touchstone for numer-

231 Douglas Baird makes a somewhat similar point. See Baird, supra note I78, at 589 ; see also Robert K. Rasmussen, An Essay on Optimal Bankruptcy Rules and Social Justice, I994 U. ILL. L. REV. I, I2-I4 (emphasizing the importance of ex ante effects).

232 Somewhat counterintuitively, harsh bankruptcy laws tend to encourage relational governance outside of bankruptcy and a less market-driven approach to corporate law generally. See Skeel, supra note 30, at 1339-46.

233 See $i d$. 
ous court decisions and every subsequent academic discussion on the subject. Not only was Countryman a charter member of the consumer protection movement, he also played a pivotal role in persuading the bankruptcy bar to support, and Congress to adopt, important protections for consumers in bankruptcy. Countryman wrote a groundbreaking bankruptcy casebook, participated prominently in the bar's leading organizations, testified regularly before Congress, wrote briefs for important cases, and authored numerous influential articles.

Underlying all of Countryman's efforts was a longstanding commitment to civil liberties. Countryman's core values were evident from the beginning of his career, in his unyielding support of the defendants in the loyalty cases of the I950s. They also informed his persistent campaign on behalf of consumer debtors. More than those of any other academic, Vern Countryman's commitments have colored the thinking of current progressive bankruptcy scholars. Like Countryman, more recent progressives promote the interests of individual debtors and a broadly construed fresh start, often join forces with the bankruptcy bar, and resist the incursions of law and economics. I have argued that the progressive vision has been distorted in some respects in its translation to the present. But this disconnect should not obscure the important continuities. Progressive theory has retained both its vitality and its influence in the work of Elizabeth Warren and other current progressives; and there is little question where, and from whom, their inspiration came. 